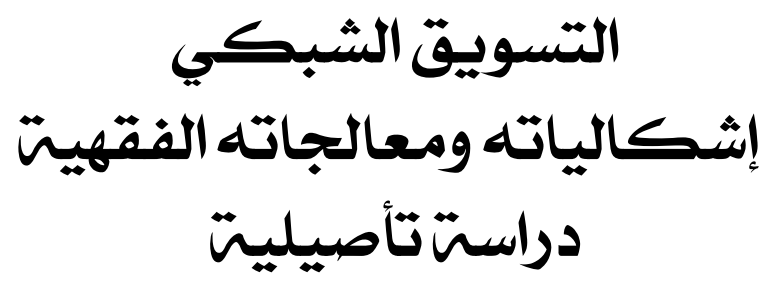

إعداد الدكتور

محمد عباس عبد العزيز علي عاشور مدروس الفقه

كليتا الشريعتّوالقانون بدمنهور 

التسويق الشبكي ، إشكالياته ومعالجاته الفقهية

دراسة تأصيلية

محهد عباس عبدالعزيز علي عاشور قسم الفقه العام- كلية الشريعة والقانون بدمنهور - جامعة الأزهر - محافظة البحيرة - جمهورية مصر العربية

البريد الإكتروني: Muhammadabbas.35@azhar.edu.eg

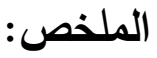

يُعَدُّ التسويق الشبكي من القضايا الفقهية المستجدة، وقد دعت العديد من المؤسسات الفقهية والإفتائية والباحثين المتخصصين في الفقه والاقتصاد للنظر في مفهومه ومقاصده والحكم الفقهي له والآثار المترتبة عليه، وقد زادت إثكالية النظر الفقهي في هذه النازلة مع قصور التصور المختلف الأوجه لها، ومن ثمَّ فهذا البحث يعرض مفهوم التسويق الشبكي، والفرق بينه وبين غيره، والتكييف الفقهي للتسويق

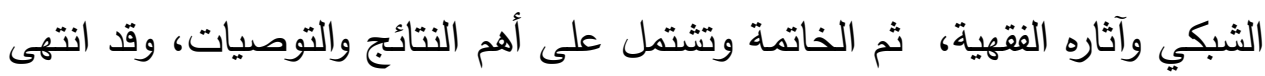
البحث إلى حرمة التسويق الشبكي في صورته الحالية التي تتقاسم سماتها العديد من الشركات وإن اختلفت مسمياتها، وأن السبب في اضطراب فتاوى التسويق الشبكي مرجعه لعدم التروي الفقهي أحيانًا، والرجوع بدقة إلى أهل الاختصاص الاقتصادي للوقوف على التصور السليم؛ ليينى عليه الحكم الفقهي، وإذا توفرت بعض المعالجات الفقهية فإن التسويق الشبكي يصبح مشروعًا وتزول عنه إثكاليات

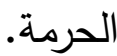

الكلمات المِفتاحية: التسويق - الشبكي - الهرمي - إثكاليات التسويق معالجات فقهية . 
التسويق الشبكي إثكالياته ومعالجاته الفقهية

Network Marketing: Its Problems and Jurisprudential

\section{Treatments}

\section{original study}

Muhammad abbas abdelaziz ali ashour

Department of Jurisprudence - Faculty of Sharia and Law in Damanhour, Al-Azhar University, El- Bohira, Arab Republic of Egypt

E-mail: Muhammadabbas.35@azhar.edu.eg

\section{Abstract:}

Network marketing is one of the emerging jurisprudential issues, and it has called on many jurisprudential and fatwa institutions and researchers specialized in jurisprudence and economics to consider its concept, purposes, jurisprudence and its implications Hence, this research presents the concept of network marketing, the difference between it and others, the jurisprudential adaptation of network marketing and its jurisprudential effects, then the conclusion and includes the most important results and recommendations. The reason for the confusion in the fatwas of network marketing is due to the lack of jurisprudence sometimes, and to refer to it carefully to the people of economic competence to determine the correct perception; In order for the jurisprudential ruling to be built on it, and if some jurisprudential treatments are available, then

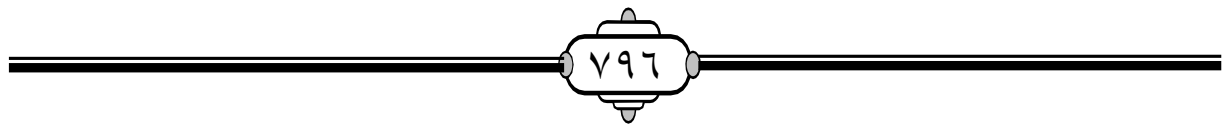


network marketing becomes legitimate and the problems of sanctity will be removed from it

Key Words: Network-hierarchical- marketing-Marketing

problems.

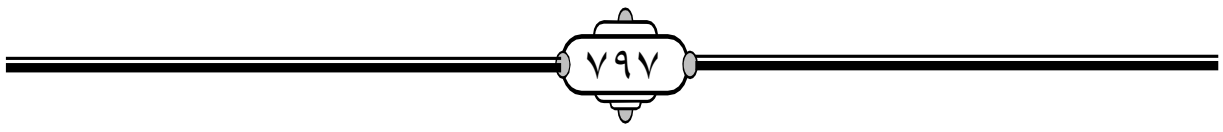




\section{مقدمة}

الحمد الله والصلاة والسلام على سيدنا تحمد رسول الله، وعلى آله وصحبه أجمعين،

وبعد:

فإن المتأمل في سرعة حركة الحياة الاقتصادية بوسائلها من بيع وشراء وعرض وطلب يجد تدافعًا غير عاديًا في تحقيق الربح، وربما كان ذلك أحد سمات الحياة المعاصرة، وهي: الرغبة في تحقيق الربح والكسب للأفراد والدول على حدٍ سواء، وإن كان ذلك كذلك فإن النفس البشرية تستحدث وتبتكر من الوسائل التي تلبي رغبتها هذه، ومن جملة ما ابتكره أرباب الشركات لتحفيز المشترين على الدخول في منظوماتها الربحية وملازماتها ما يعرف بالتسويق الشبكي، ولقد كان لأهل الفقه نظُر حول التكييف الفقهي لهذه الوسيلة المعاصرة ومعالجتها، وتقديم البدائل الثرعية لها إن ذهبت المذاهب المعاصرة إلى الحرمة مذهبًا. ولقد حاولت في هذا البحث إبراز ما انتهى إليه الاجتهاد الفقهي المعاصر حول التسويق الشبكي وآثاره الاقتصادية والفقهية؛ لعلها تكن لبنة في صرح الاجتهادات البحثية والمعالجات الفقهية المعاصرة، وفيما يلي بيان بأهمية الموضوع ومنهج البحث وخطته:

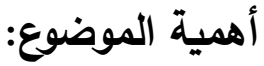

أولاً: كثرة تساؤلات الشباب حول ما يتعلق بالتسويق الشبكي خاصة مع ارتقاع نسبة البطالة، والرغبة الجامحة في التكسب والتربح والثراء السريع. وهذه التساؤلات تأتي متزامنة مع تمدد هذه الشركات في المجتمعات الغربية والعربية، وقد جاء في إحدى الدراسات أن العاملين في هذا التسويق به مليون شخص في العالم، وفى كل أسبوع ينضم . . ب ألف شخص جديد، ويحقق هذا النوع من التسويق مبيعات تصل إلى ·ـ مليار دولار سنويًا (').

(1) التسويق الثبكي( حقيقته وحكمه)، د. ححمد الصواط، صه9. 
ثانياً: نشاط الدعوات للدخول في منظومة التسويق الشبكي، وتتافس الشبكات على استقطاب الشباب والترويج لذلك ببعض الفتاوى الصادرة من أفراد ومؤسسات

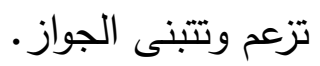

ثالثًا: كثرة اللغط حول بعض الفتاوى والتي صدرت في مرحلة مبكرة قبل الوقوف التام على طبيعة المعاملة ومعرفة آثارها الاقتصادية السلبية. رابعًا: كثرة المشكلات التي نتجت عنها بين أوساط المنتفعين منها، وعدم وجود تصور واضح لآثارها من استحقاق الثن، والربح والرد بالعيب، ومدى التوافق مع صحيح القانون، والرجوع بحقوق العقد بين من يزعمون وكالتهم عن الشركات الكبرى وبين تتصل الشركات عن تحمل تبعات تصرفات هؤلاء. خامسًا: إبراز شمولية وخالدية الثربعة، وقدرتها بما منحها الله من مبادئ وقواعد وأصول تتبني عليها الأحكام أنْ توضح للناس ما أُشكل عليهم في أمورهم، وأن اجتهادات فقهائها تقوم على الدمج بين منظومة القيم والمنظومة التشريعية والاقتصادية ـ كما سيأتي توضيحات المختصين في تقارير عدة حول أزمة التحول النفسي للمنتفع بعد فترة وربما خروجه عن منظومة القيم. سادسًا: المساهمة في توعية الثباب بطبيعة الصورة هذه وآثارها، ولقد كنت أتصور أن لهذه الأبحاث أثرًا محدودًا في مثل هذه المسائل حتى وجدت بعض لهض المسوقين لهذه لطريقة يستشه ببحث ترقية لأحد الأساتذة الذى انتهى فيه إلى جوازها، والتي تبين بعد ذلك توقف الاستاذ المشار له عن القول بالجواز بعد ثبوت بعض الممارسات السلبية كما سيأتي بيانه في البحث.

\section{إثكالية البحث}

تتمحور إشكالية البحث في الإجابة على التساؤلات الآتية:

ما مفهوم التسويق الشبكي والفرق بينه وبين غيره؟ ما هي السمات المشتركة للتسويق الشبكي؟ 
ما هو التكييف الفقهي للتسويق الشبكي والحكم الفقهي له؟ ما هي أسباب اختلاف الفقهاء حول التكييف الفقهي للتسويق الثبكي؟ كيف يمكن معالجة إشكالياته من خلال مقترحات وبدائل ممكنة؟ منهج البحث اقتضت طبيعة الموضوع القائمة على تتاول الجزئيات من منظور الاقتصاد، ثم

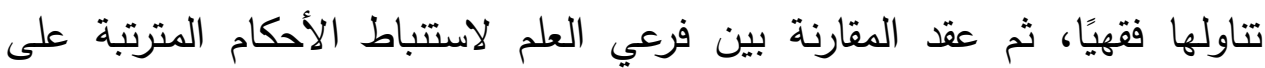
الاخول في هذه الصورة الحديثة إلى قيام البحث على مجموعة من المناهج تداخلت واندمجت فيما بينها تحقيقًا لأكبر قدر من التناول المثر وهى كالتالي: المنهج الوصفي: وفيه يصف البحث الحال الحقيقي لشركات التسويق الشبكي، ويعرض النصوص الشرعية ذات الصلة بالموضوع كي يستتبط منها لاحقًا الحكم الثرعي.

المنهج التحليلي: يقوم البحث بتحليل المقدمات الوصفية [ سمات الشركات النصوص الثرعية - الآراء الفقهية القديمة والمعاصرة ] بفهم أصولها الفقهية وأسبابها وسياقاتها الواردة فيها ومدى انطباقها على الشركات موضوع البحث. المنهج الاستنباطي: يستنبط البحث من خلال ما سبق الحكم الفقهي، أو يستنبط ما يدعمه من واقع النصوص الثرعية والآثار الاقتصادية والاجتماعية كما يستنبط معالجة فقهية لأوجه الإشكاليات التي ترد على هذه المعاملة. المنهج المقارن: يقارن البحث بين الآراء الفقهية بغية الوصول إلى الراجح منها بحسب فهم البحث للنصوص ومقتضياتها ومآلاتها. المنهج التأصيلي: تأصيل وتوثيق ما يرد ذكره في البحث من محتوى علمي فقهي واقتصادي وغيرهما من مصادره ومراجعه العلمية المعلومة عند أرباب

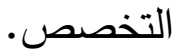
وبناء على هذه المناهج عرض البحث للمحتوى على النحو الآتي:

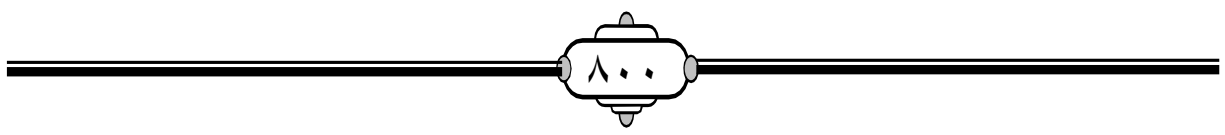


اـ عرضت الرأي المختار من التعريفات مباشرة دون خوض في تفاصيل الاختلاف فيها؛ حيث لا يترتب عليه ثرة فقهية ذات صلة بالحكم المرجو الوصول له، أو نظرًا لما تقتضيه طبيعة البحوث التخصصية. rـ عرضت السمات المشتركة بين الشركات العاملة في مجال التسويق الشبكي دون تخصيص البحث بأي منها؛ ليكون معبرًا عن مجموعها لتعميم الفائدة . rـ عزو النصوص والآراء إلى مصادرها الصحيحة وتوثيق ذلك في الهامش. ع- التوسط في عرض وجه الدلالة بين المصادر القديمة والمعاصرة جمعًا بين مقتضيات الأصالة والمعاصرة. م. تتوع المصادر الفقهية والاقتصادية توثيقًا لمادة البحث وتأكيدًا لصحة ما ينتج عنه. T. اكتثيت بذكر اسم المرجع، وأحيانًا مؤلفه - لا سيما- عند تشابه أسماء المراجع، وتركت بيانات المصادر من الطبعة والتحقيق وسنة النشر إلى نهاية البحث حيث قائمة مصادر البحث ؛ تجنبًا للإطالة والتكرار . خطة البحث: اقتضت طبيعة الموضوع إلى عرضه في مقدمة ومبحثان وخاتمة، على النحو التالي: - n المقدمة: تشتمل على أهمية البحث ومنهجه وخطته. المبحث الأول: مدخل إلى مفهوم التسويق الشبكي، والفرق بينه وبين غيره، وفيه مطلبان:

المطلب الأول: مفهوم التسويق الشبكي لغَّة واصطلاحاً. المطلب الثاني: أهم سمات التسويق الثبكي، والفرق بينه وبين غيره. المبحث الثاني: الحكم الفقهي للتسويق الشبكي وآثاره الفقهية، وفيه مطلبان: المطلب الأول: الحكم الفقهي للتسويق الشبكي. المطلب الثاني: الآثار الفقهية للتسويق الشبكي.

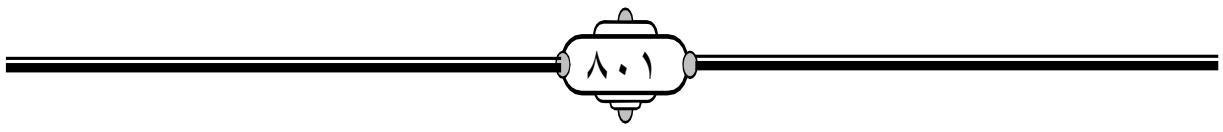


المطلب الثالث: المعالجات الفقهية لإشكاليات التسويق الشبكي.

( مقترح في تصحيح الصورة الحالية)

الخاتمة: وتثتمل أهم النتائج والتوصيات.

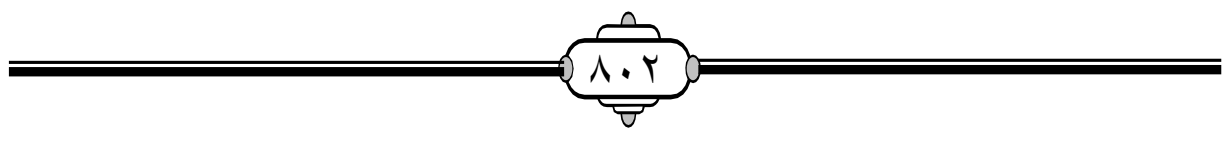




\title{
الإبمث الأول
}

\author{
هدخل إلى هفهوم التسويق الثبكي \\ والفرق بينه وبين غيره.
}

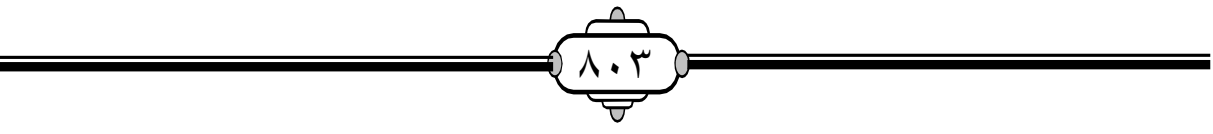




\section{التسويق الثبكي إثكالياته ومعالجاته الفقهية}

\section{المبحث الأول}

\section{مدخل إلى مفهوم التسويق الشبكي، والفرق بينه وبين غيره}

تمهيد: يقتضي الحكم الفقهي السليم لأى واقعة مستجدة تصورها تصورًا سليمًا تحقيقًا لقاعدة: الحكم على الثيء فرع عن تصوره، ومن ثمَّ فهذا المبحث يقوم على بيان مفهوم التسويق الشبكي، والفرق بينه وبين غيره، ليقرر البحث الحكم الفقهي عقب ذلك. وذلك في مطلبان:

المطلب الأول: مفهوم التسويق الثبكي لغة واصطلاحاً، وفيه فرعان: الفرع الأول: مفهوم التسويق الشبكي لغَة.

\section{أولًا: مفهوم التسويق لغًة:}

التسويق: تفعيل مشتقُ من السَوّق والسوُق، يقال تسَوّق فلان: أي باع واشترى. والسوَق: بفتح الواو معناها: القيادة والتقدم، و والسُوق: هي موضع البيوع، وتُجْمَعُ على أسواق، وسميت بذلك؛ لأن التجار تجلب لها البضائع ويسوقون بياعاتهم

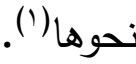
وهو ينبئ عن عملية تفاعلية يُفهم منها: وجود موضع للسلعة سواء أكان سوقًا حقيقيًا أو حكميًا كالأسواق الإكترونية فالمعنى اللغوي يشمله، وليس للسوق إذًا حدودًا جغرافية أو نطاق مكاني فيقال سوق السيارات بما يشمل كافة مناطق بيعها مثنًا.

\section{ثانيًا: مفهوم الشبكي لغًة.}

مشتقُ من شَبَكَكَ ومعناه: الخلط والتداخل، يقال: شَبَّكّ الثَّْيْه شبكا إذا تدَاخل

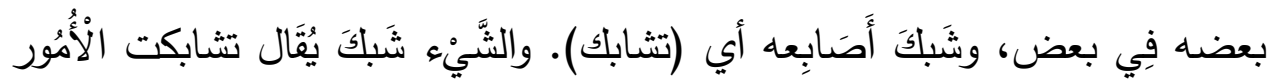

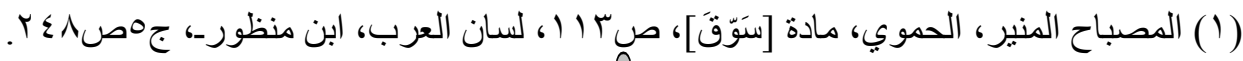


اخْتَلَط بَعْضهَا بِبَغْض. واشتبك أي تشابك يُقَّال: اشتبك الظلام إذا دخل واختلط، ومنه الثِبِالك إذ تتداخل الخيوط فيها وتختلط. ويقال شبكت النجوم واشتبكت وتشابكت: تداخلت واختلطت في بعضها البعض ا ـ وسميت هذه الصورة به؛ لأن التعامل بها يقوم على شبكة متداخلة ومختلطة من العلاقات بين مجموع المنتجين والبائعين والمشترين. ويُلاحظ أن مفهوم التسويق والثبكي بينهما مناسبة ومقاربة إذا يختلط ويندمج التسويق القائم على التفاعل بين مفردات عملية التسويق من منتج ومورد وبائع ومشتري وسوق وطريقة عرض وثمن وغير ذلك مثل اختلاط الشبكة وتداخل خيوطها، وقد يسميها البعض شبكات العملاء.

الفرع الثاني: مفهوم التسويق الثبكي اصطلاحًا. أولاً: مفهوم التسويق اصطلاحًا.

مما سبق يتضح أن التسويق تفعيل يتضمن وجود منتج و ثمن ومنافذ للعرض حقيقة أو حكمية ومشترين وبائعين و خطة ترويج وأسس للتثمين ودراسات تحليلية حالية وتتبؤية للسوق ورغبات المستهلكين، وغير ذلك.

وفي ضوء ذلك يمكن تعريف التسويق اصطلاحًا بأنه: تخطيط وتتفيذ عمليات تطوير وتسعير وترويج وتوزيع للسلع والخدمات، بغية خلق عمليات التبادل التي

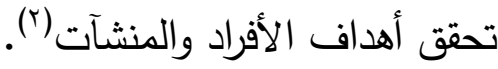

(1) المعجم الوسيط، مجمع اللغة العربية بالقاهرة، جاص الاء، مختار الصحاح، الرازي

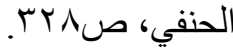

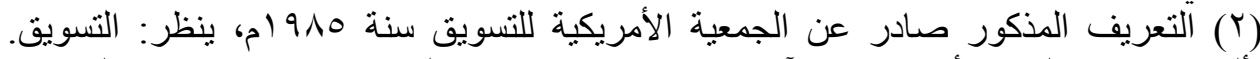
تأليف: د. عبدالسلام أبو قحف وآخرون، صـه؛، مبادئ التسويق، د. محمد فريد الصحن،

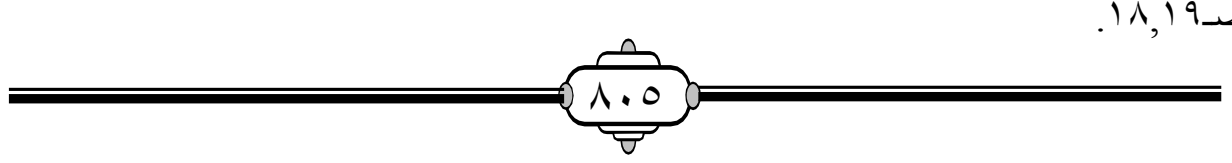




\section{ثانيًا: مفهوم التسويق الثبكي اصطلاحًا باعتباره مركبًا.}

يقوم التسويق الشبكي على مجموعة مرتكزات وهي: عملية توظيف للأفراد، وبرنامج للتسويق، وخطة توزيع الأرباح، ومنتج. ومن خلال ما سبق يمكن لنا أن نستخلص تعريف يتتاول هذا المفهوم بمعناه الشامل الذى يُشَكِّل قَاسِمًا بين الشركات الداعية له والمرغبة فيه مهما اختلفت مسمياتها (')، وهو: ( نظام لتوزيع السلع والخدمات بأرباح مالية متتامية بحسب ضم أكبر عدد من المستهلكين وفق شروط مسبقة).

ويعتمد هذا النظام على شبكات في شكل شجرة ذات أفرع عديدة أو في شكل هرم في درجات ومستويات متدرجة، ويحصل العضو الأول في الثجرة أو الهرم على عمولات عن كل عضو جديد يدخل فيهاب(r).

(1) تباينت تعريفات التسويق الثبكي بحسب اجتهادات البعض في إبراز طبيعته ومكوناته وسماته

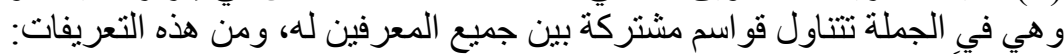

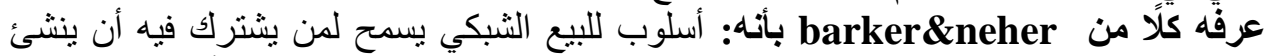

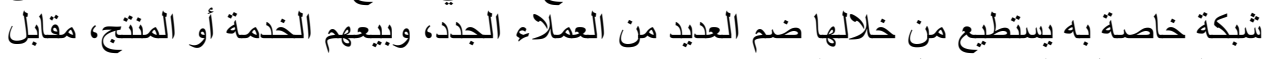

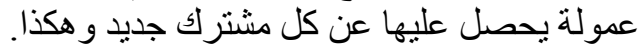

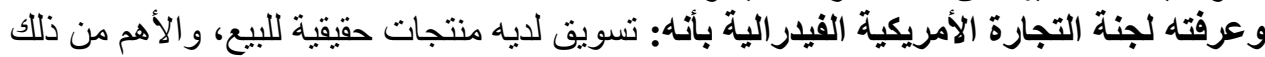

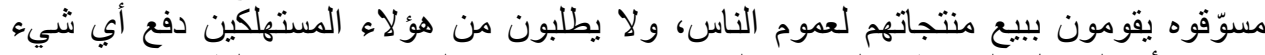

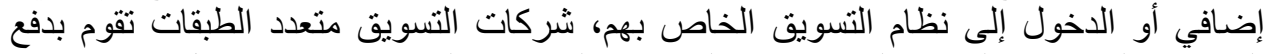
العمو لات لقائمة طويلة من الموزعين [ البائعين]، لكن هذه العمولات لتئ تكون مقابل بيع منتجات

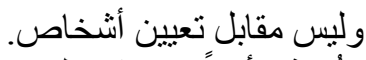
ويُعرف أيضًا: الاشتر الك بنظام تسويق شبكي يجلب فيه كل مشارك مشاركين آخرين، وكل من ون

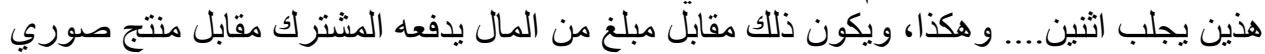

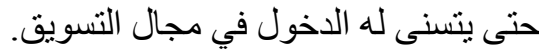

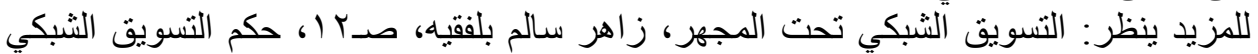

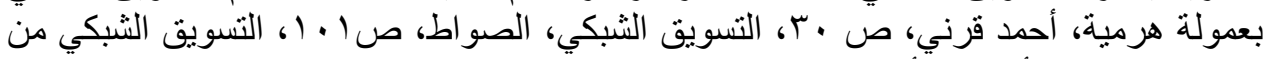

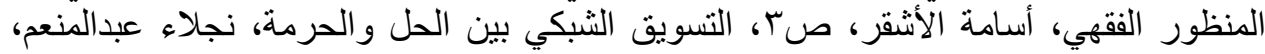

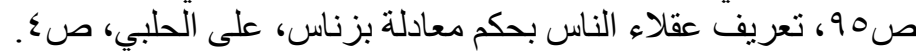

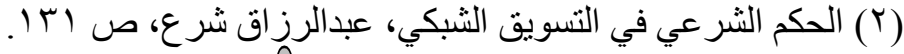


المطلب الثاني: أهم سمات التسويق الثبكي، والفرق بينه وبين غيره، وفيه فرعان: الفرع الأول: أهم سمات التسويق الشبكي. من خلال مراجعة أنظمة الشركات العاملة في مجال التسويق الشبكي وما كتبه خبراء الاقتصاد وما يقوم به المسوّقين لهذه الشركات يمكن أن نستخلص أهم السمات المشتركة بين هذه الشركات في الآتي:

أولًا: شراء منتج كثرط للحصول على العمولات والدخول في عملية التسويق، ويصبح العميل له كود أو حساب أو رقم سري يدخل به ليتعرف على منتجات الشركة ويتابع سياستها وأنشطتها.

ثانيًا: توظيف العملاء الجدد أو المستهلكين أو المسوّقين الجدد في سلسلة غير متناهية نظريًا، أما عمليًا فلابد وأن تتوقف عند حد، سواء بعجز المسوّق عن استقطاب آخرين أو خروجه من منظومة التسويق. ثالثًا: الأسبق والمتقدم في الاشتراك هو الأكثر ربحًا حيث يضاف له عوائد من المسوّقين اللاحقين له، والعكس كذلك إذ المتأخر في الدخول للنظام يكون أقل ربحًا، وأكثر مخاطرة في تعويض ما دفعه من قبل. رابعًا: الدخول في النظام لا يتم إلا بعميل أو مسوّق سابق، ويكون الراغب في الاخول لنظام التسويق الشبكي - في أي شركة - بمفرده فرصة لإدارة الشركات أن تلحقه بمن تريد من المقربين منهم فيضيفون لأرصدتهم عميلًا جديدًا. خامسًا: الاهتمام والحافز في النظام ليس قائمًا على شراء المنتجات أو بيعها، وإنما على استقطاب العملاء والمسوّقين والمشتركين الجدد. فالمنتج ليس مقصودًا أساسيًا للمتقدم أو المشتري بل قد يشتري له ولأسرته أشياء لا حاجة لها لينال العوائد ويُعَوَضُ ما دفعه في شراء المنتج.

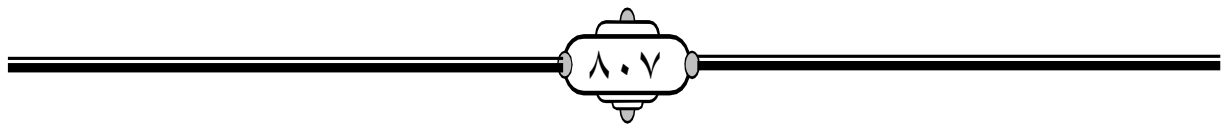


سادسًا: أغلب المنتجات تُستهلك من قِبل المسوّقين لا المستهلكين خلافًا للتسويق التقليدي.

سابعًا: تضع الشركات حد أقصى لعوائد المستويات المتقدمة للشركة حتى لا تلتهم العمولات رأس مال الشركة('). ويمكن أن نضع صورة متثابهة متقاربة لعمل هذه الشركات تجمع بين السمات السابق ذكرها تتمثل في الآتي: أن يشتري الشخص منتجات الثركة مقابل الفرصة في أن يقنع آخرين بمثل ما قام به [ أن يشتروا هم أيضًا منتجات الشركة]، ويأخذ هو مكافأة أو عمولة مقابل ذلك. ثم كل واحد من هؤلاء الذين انضموا للبرنامج سيقنع آخرين ليشتروا أيضًا، ويحصل الأول على عمولة إضافية وهكذا.

لنفترض أنَّ زيدًا قرر أن يشتري منتجات شركة من هذه الشركات مقابل . . دولار تعطيه الشركة بناء على ذلك الحق في أن يسوق منتجاتها لآخرين مقابل عمولات محددة. يقوم زيد بإقناع شخصين بالانضمام للبرنامج، بمعنى أن يشتري كل منهما منتجات الشركة، ويكون لهما الحق في جذب مسوقين آخرين مقابل عمولات كذلك، ثم يقوم كل من هذين بإقناع شخصين آخرين بالانضمام (؟). الفرع الثاني: الفرق بين التسويق الشبكي وبين غيره. أولًا : الفرق بين التسويق الشبكي والتسويق التقليدي.

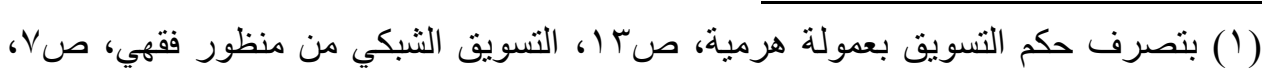

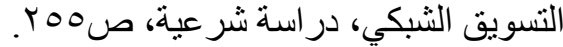

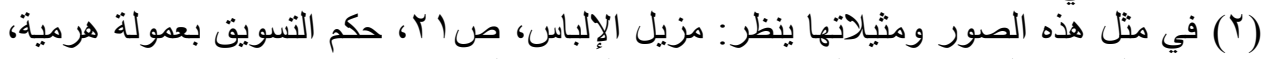

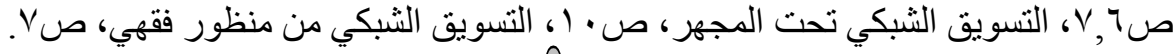

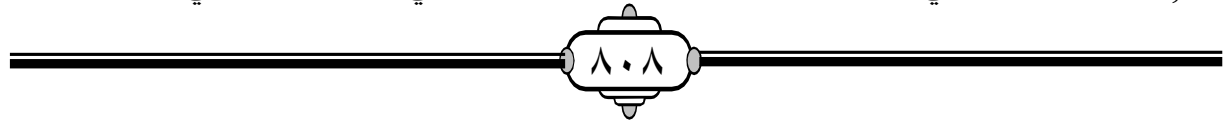




\section{التسويق الشبكي إشكالياته ومعالجاته الفقهية}

سبق تعريف التسويق التقليدي بأنه: تخطيط وتتفيذ عمليات تطوير وتسعير وترويج وتوزيع للسلع والخدمات؛ بغية خلق عمليات التبادل التي تحقق أهداف

الأفراد والمنشآت(') - (')

وصورة التسويق التقليدي: تتمثل في الاعتماد على الوسطاء المتعددين بين المنتج والمستهلك، فالمنتج لابد له أن يمر بسلسلة من الوسطاء قبل أن يصل إلى المستهلك الأخير، ومن جملتهم: الوكيل والموزع والمحل. كما أن المُنْتِج بحاجة إلى لى دعاية وإشهار واللذان يكلفان مبالغ مالية كبيرة يتحملها المنتج. بينما في التسويق الشبكي لا يوجد كل هؤلاء الوسطاء، ويقوم النظام بالربط بين الشركة والعميل مباشرة عن طريق المسوّق(؟). ومن خلال ما سبق يتضح أوجه الفرق بينها في الآتي: في التسويق التقليدي يتوفر منتج حقيقي مقصود شراؤه؛ لتلبية حاجة المستهلك، ولا خلاف في إباحته بضوابط، ويشتريه برغبته بدون شرط مسبق مع توسط الموزعين والمندوبين في التسلسل المعروف. أما التسويق المباشر فالمنتج وإن وُجِدَ لكنه غير مقصود غالبًا مع إلزامه بالثراء أو دفع رسوم اشتراك ولا يوجد وسطاء إلا المسوّق، وقد اختلف أهل العلم في حكمه.

ثانيًا: الفرق بين التسويق الشبكي والتسويق الهرمي.

يُعَرَفُ التسويق الهردي بأنه: نظام استحدثته بعض الشركات لتحقيق الأرباح، تكون المكافأة فيه على استقطاب العملاء الجدد، وتقدر بطريقة حسابية هرمية

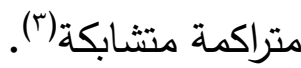




\section{التسويق الشبكي إشكالياته ومعالجاته الفقهية}

أو هو: ارتباط العائد للمشترك على دخوله في مستوى مرتبط بمستويات أخرى

تُشكل بمجموعاتها طبقات، ويزداد العائد كلما كان موقع المشترك أقرب إلى المشترك

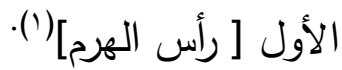

ومن خلال ما سبق بيانه في تعريف التسويق الشبكي يمكن لنا أن نحدد أبرز نقاط الاختلاف بينهما في الآتي:

أن التسويق الشبكي يقوم على بيع منتجات حقيقية وإن كانت غير ذات فائدة أو مُجْديَةٍٍ لكن التسويق الهرمي المنتج فيه صوريًا أو منعدمًا(؟). أن التسويق الشبكي بيع منتج بثمن قربب دن سعر السوق دون مبالغة فيه، وهو ما يزعمونه كي يستقطبون المستهلك أو العميل الجديد، لكن ثمن المنتج في التسويق الهرمي مبالغ فيه، وهو ما ينبئ عن استغلال وغرر، ويؤكد مزاعم من

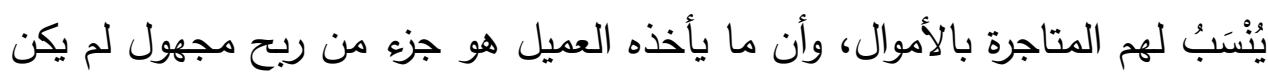
في الاتفاق المسبق، ولكن الغرض كان استقطابه لشراء السلعة.

والتسويق الشبكي قد وقع خلافًا بين المعاصرين في توصيفه وتكييفه الفقهي، والجدير بالذكر أن التسويق الهرمي - بدون منتج - لا خلاف فيه.

وأما ما يتققا عليه معًا: هو الوعد والتحفيز بالأبباح الخيالية، وأنه لا يمكن الدخول في منظومة التسويق إلا بعد شراء المنتج وضم العملاء، وربما تم دفع رسوم للاشتراك في النظامين.

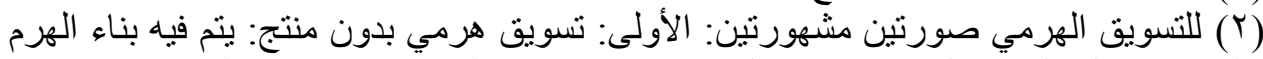

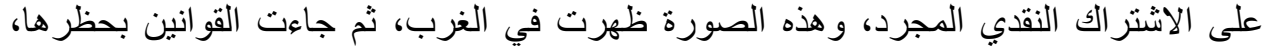

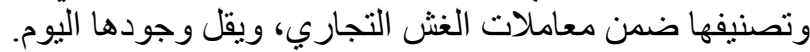

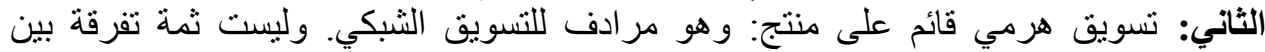

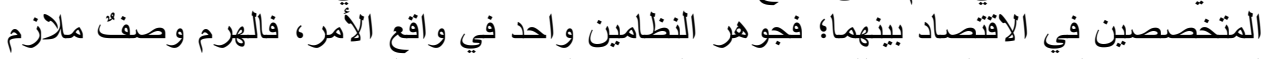

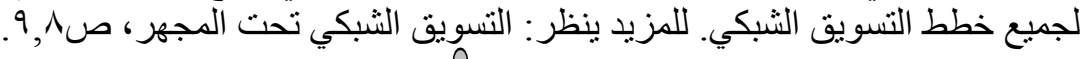




\section{المبمث الثاني \\ الهكم الفقمي لاتسميق الثشبكي \\ والآثار المثزتبة عليه.}

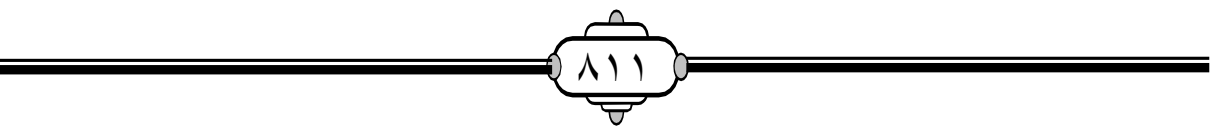




\section{التسويق الثبكي إثكالياته ومعالجاته الفقهية}

\section{المبحث الثاني}

الحكم الفقهي للتسويق الشبكي والآثار المترتبة عليه

\section{وفيه مطلبان:}

تمهيد: تتوعت صور الشركات العاملة في مجال التسويق الشبكي، وحتى يُعَبِّر البحث عن هذه المعاملة، فإنه يجدر القول بأنَّ هناك سمات مشتركة تجمع بين هذه الشركات، وإن اختلفت في إجراءات ومظاهر بسيطة إلا أن الحكم الآتي ذكره يستوعب جميع الشركات التي تجمع هذه السمات وتقع بينها هذه القواسم المشتركة، وسوف نتناول الحكم الفقهي لها وآثاره الفقهية في المطالب الآتية: المطلب الأول: الحكم الفقهي للتسويق الشبكي، وفيه فروع: الفرع الأول: سبب اختلاف الفقهاء في حكم التسويق الثبكي. يُمْكِنُ أن يَرْجِع سبب اختلاف الفقهاء في هذه المسألة للآتي: أولًا: ضعف أو انعدام التصور الفقهي السليم لمضامين التسويق الشبكي؛ بسبب حداثة الطريقة، وتتوع الشركات، وتأخر التوضيح الاقتصادي اللازم للفقيه والمفتي قبل الحكم عليها، والتعجل في إصدار الفتاوى بشأنها بناًء على ما يُحدِّث به وهيه المسوقين لها لا على واقع الأمر وحقيقته. ثانيًا: اختلاف الفقهاء المعاصرين في التكييف الفقهي للواقعة على آراء عدة يمكن عرض موجزها كالتالي ('):

(1) سيأتي الحديث تفصيًال عن أصحاب هذه الاجتهادات و الأقوال، وبيان أدلتهم، وما ورد عليها

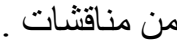

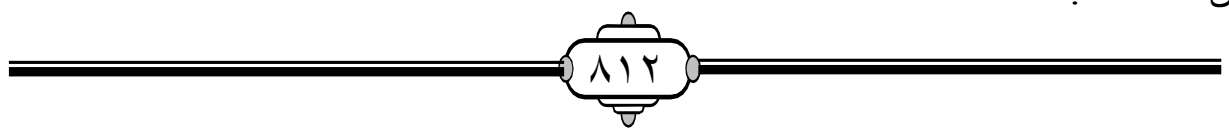




\section{التسويق الثبكي إثكالياته ومعالجاته الفقهية}

_ - القائلون بالجواز: منهم من رآها معاملة حديثة، لتندرج تحت الأصل

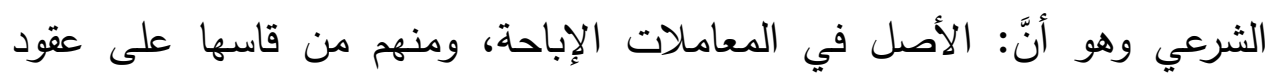
الجعالة والوكالة بأجر والسمسرة، وترتب على ذللك القول بجوازها عنده.

ـ القائلون بالحرمة: منهم من رآها مندرجة تحت ربا الفضل، وأحد صوره المعاصرة، ومنهم من رآها مندرجة تحت المقامرة والميسر والغرر والتدليس والحيل المحرمة، ومنهم من رأى آثارها السلبية اقتصاديًا واجتماعيًا وأخلاقفيًا سبيًا كافيًا

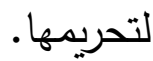

الفرع الثاني: أقوال الفقهاء في حكم التسويق الثبكي، وأدلتها ومناقشتها. اختلف المعاصرون في حكم هذه الدسألة على ثلاثة أقوال، وهي على النحو

القول الأول: ذهب بعض الفقهاء وبعض دور الإفتاء إلى جواز التسويق

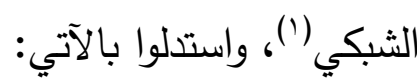

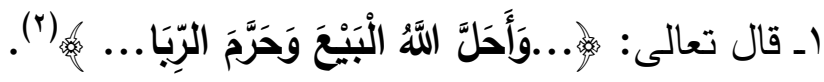
وجه الدلالة: تقرر الآية أصلًا فقهيًا بأن الأصل في المعاملات الإباحة ما لم

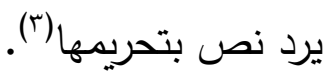

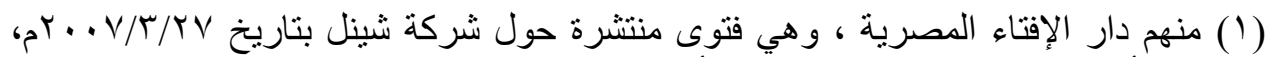

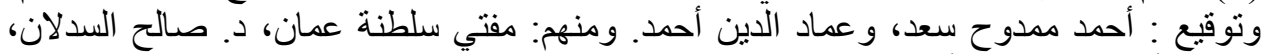
و والثيخ أحمد الدداد، د. أحمد محم السعد.

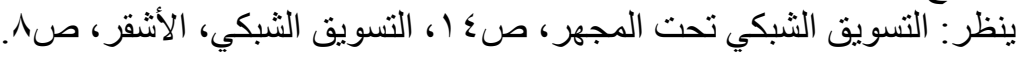

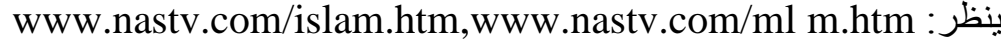
وأيضًا: http://www.saaid.net (Y) (r) وردت هذه القاعدة بعبارات مختلفة منها: الأصل في الأثشياء الحل، ما لا يعلم فيه تحريم (T) ورديه حكم الحل. 
والتسويق الثبكي من جملة المعاملات المعاصرة التي لم يرد فيها نصٌ يحرمها

فتبقى على أصل الحل (1).

ونوقش ذلك: بأن كل دليل يمكن أن يعارضه دليلّ آخر يمنع الاستدلال به، فهو إذًا دليل بشرط: السلامة عن المعارضة، فلا يجوز التمسك بالأصل هذا إلا بعد ظن لن لهن انتفاء المعارض، ويقين بعجز النفس عن الوصول إليه، والواقع يثبت نقل الأصل عن الإباحة إلى الحرمة بأدلة يفيد بعضهاء حرمة ولجئ هذه المعاملة ومن ذللك: الغرر والقمار وأكل أموال الناس بالباطل(ז)، كما سيأتي بإني

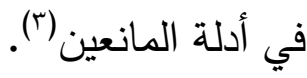
بـ يُعدُّ التسويق الشبكي نوعًا من السمسرة المشروعة حيث يأخذ المسوق العمولة

مقابل جهذه للتسويق في بيع السلعة(£). وقد جاء في نص فتوى لجنة الفتوى بالأزهر : ( إن ما تقوم به الشركة من وساطة بين المنتج والمستهلك لترويج السلعة يدخل في باب السمسرة، والسمسرة كما يقول الفقهاء جميعًا إذا لم تقدم على غش أو تدليس أو ظلم أو خيانته يكون ما يأخذه الواسط والمسار حلال لا شبهة فيه)(0).

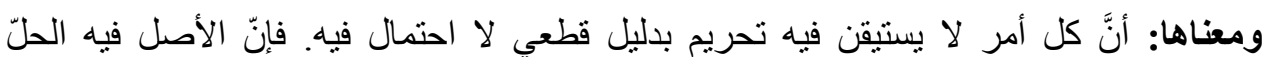

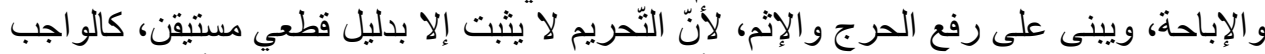

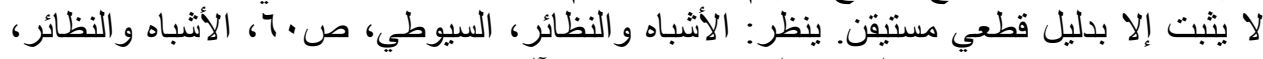

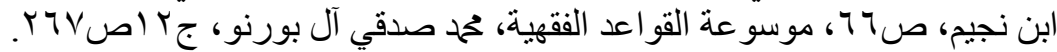

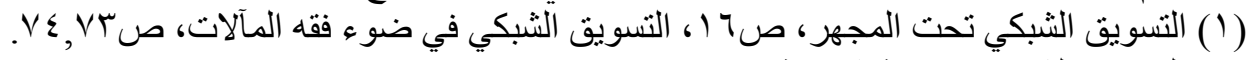

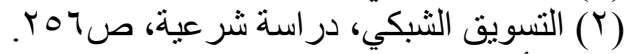

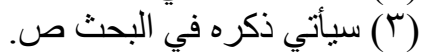
(ع) السمسرة اصطّلاحًا: الوساطة بين البائع و المشتري، والسمسار: الدلال، وهو الوسيط بين

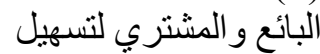

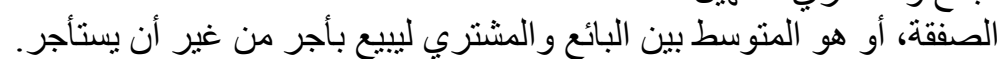

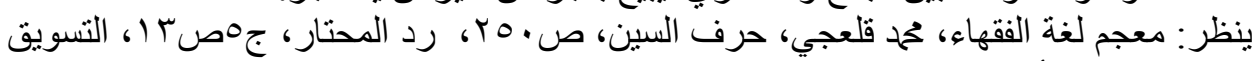

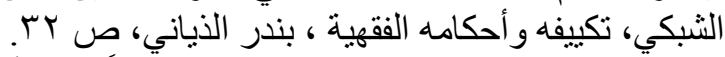

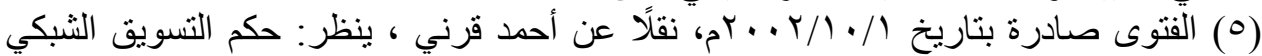

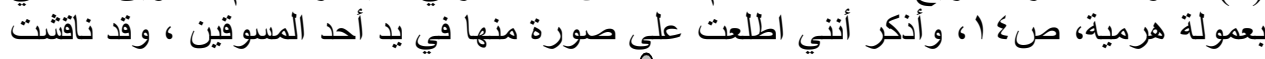


ونوقش ذلك: بأن السمسرة تخالف التسويق الشبكي من جهتين: الأولى: أن السمسار يأخذ مقابل التسويق لسلعة دون اشتراط شراءها، فهو لا يدفع مبالغ معينة ليتسنى له التسويق للسلعة المستهدفة. أما التسويق الشبكي فيُشْتَرَط عليه أن يشتريها

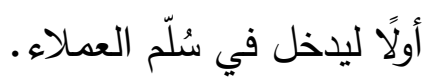

والثانية: أن السمسار يبذل الجهد في مقابل سلعة حقيقية مقصودة للمستهلك (')، أما في التسويق الشبكي فيأخذ العمولة على الترويج للعمولات والأبباح وإغراء الآخرين بها فالسلعة ليست مقصودة بينهما نظريًا وواقعيًا، كما أن الأجرة في السمسرة لابد وأن تكون معلومة(؟)، أما في التسويق فهي مجهولة مبناها الخطر والغرر لا يعلم منتهاها(ب). بـ التسويق الشبكي وكالة بأجر ، حيث تقوم الشركة بتوكيل المسوق لمنتجاتها مقابل العمولة، وتكون العمولة مقابل الجهد الذي يبذله(أ).

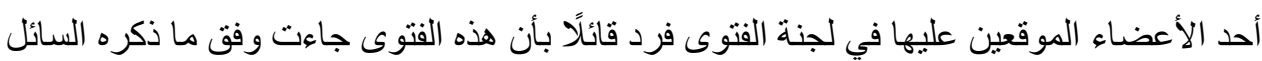

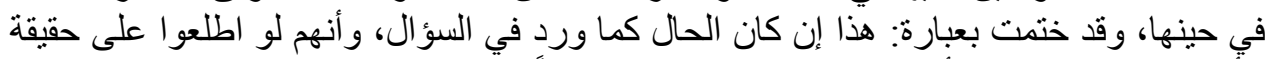

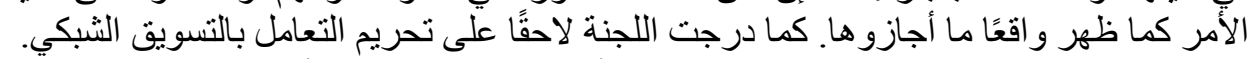

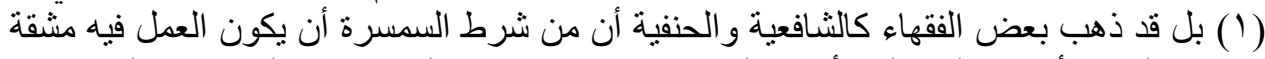

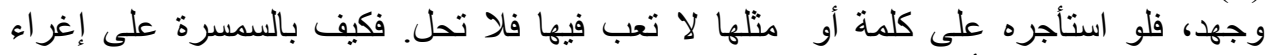
وتضليل الناس وبيع الأوهام.

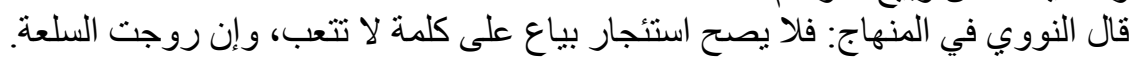

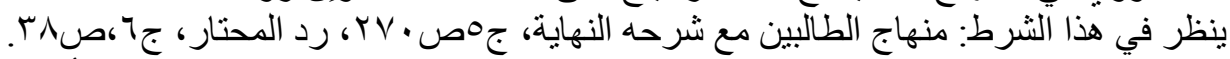

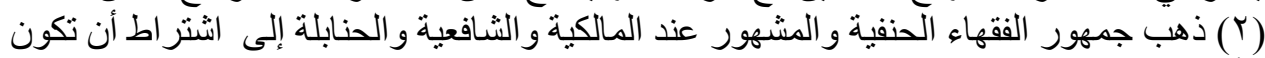
الأجرة معلومة وهي و إلا كانت السمسرة باطلة.

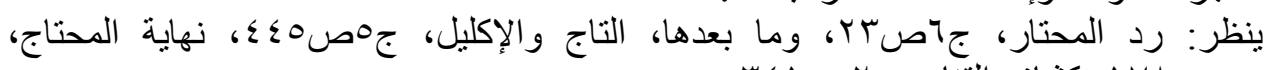

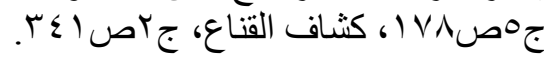

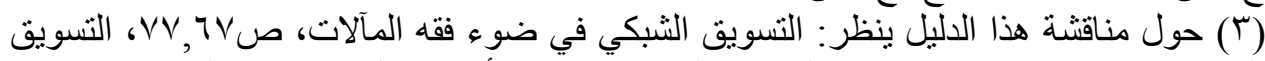

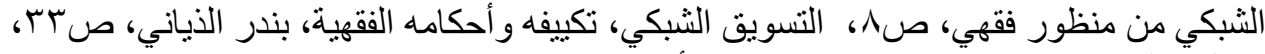

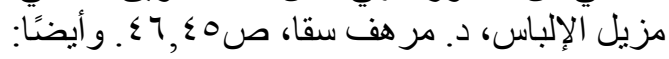

http://:www.islamonline.net/livefatwa/arabic/Browse.asp http://www.zuhayli.com/fatawa_p36.htm\#2 http://www.zuhayli.com/fatawa_p36.htm\#2

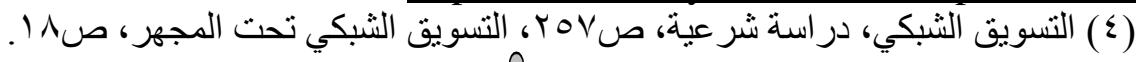


ونوقش ذلك من وجهين: الأول: أنَّ الوكيل غير مجبر على شراء المنتج،

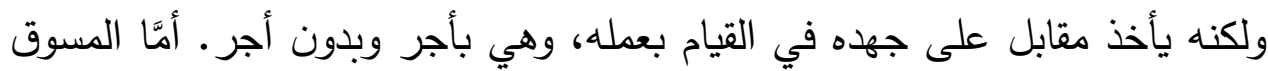
فيشترط عليه الشراء ليدخل في منظومة التسويق.

والثاني: أن عقد الوكالة من العقود الجائزة حيث يجوز لطرفي العقد أن يفسخه

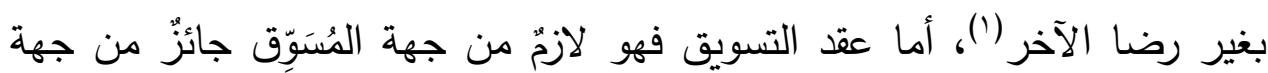

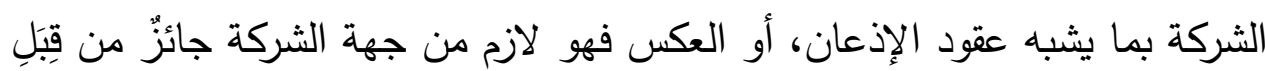
المُسَوِّقِ

فالثركة تلتزم غالبًا ولا تفسخ العقد من قِبلها ما دام المشترك ملتزم بمهته، وإلا لكان ذلك باب عبث، حيث لو كان الأمر كذلك للجأت الشركة إلى فسخ العقد الذى لهى

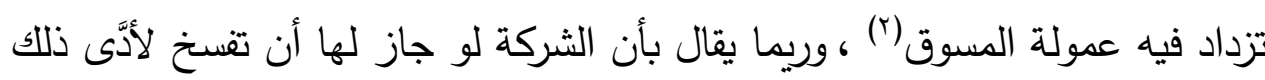
إلى تخوف وعزوف العملاء عن الانضمام لها خشية تفويت الربح عليهم، فهي تحرص على إيجاد سِمة الاستقرار التي تحفز الآخرين على الانضمام لها. بل يرى البعض: أنه أفضل للشركة أن تفسخ العقد من جهتها، وذلك عندما يقوم بتجميع أعداد كبيرة من الأعضاء ثم يعجز عن إتمام الخطوة، وأما من جهة الشركة أو الموكِل فإنَّ كثيراً من الشركات لا تلتزم بتمام الأجرة - لاسيما - لأولئك

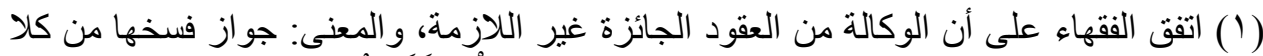

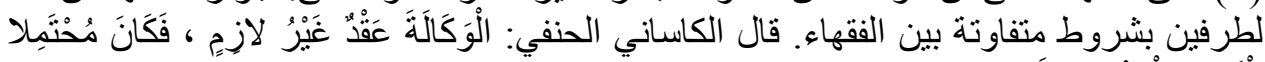

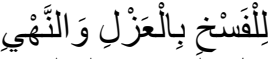

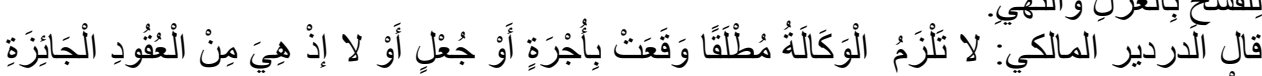

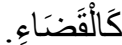

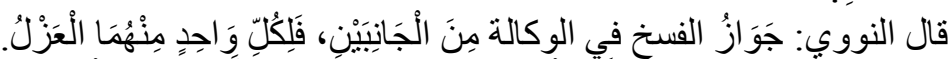

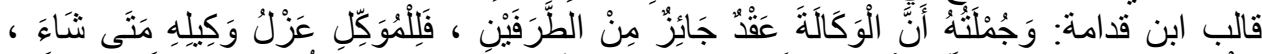

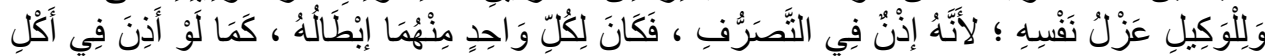

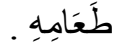

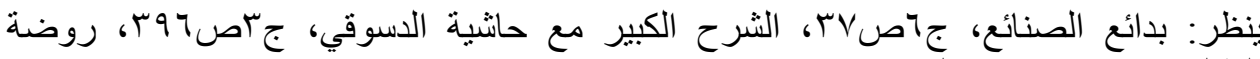

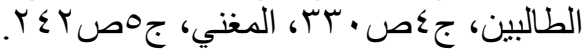

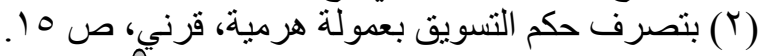


الذين هم في أسفل الهرم، وبعض الشركات لا تعدها أجرة بل تتص على أنها هدية

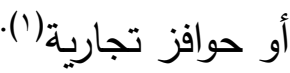

والثالث: على فرض التسليم أنه عقد وكالة بأجرة فقد تقدم أن من أركان الوكالة كون الأجر معلوماً نوعَ علمٍ لا يعظم فيه الغرر، أما هنا في التسويق الشبكي فإن العمل وهو التسويق يحتوي على الغرر؛ لأن المشترك لا يدري هل ينجح في

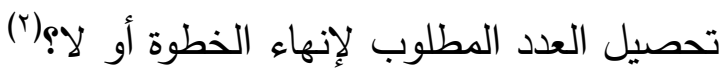
عـ التسويق الشبكي من باب الجُعَالة'، حيث تقدم الشركة جُعْلا للمسوق نظير

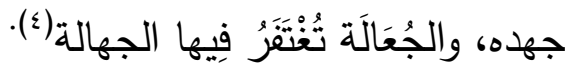

\section{ونوقش ذللك من وجوه:}

الأول: بأنه في عقد الجُعَالة لا يُعطى الجُعل إلا إذا استطاع أن يحقق موعود عقد الجُعَالَة، فإن لم يستطع يكون قد خسر وقته فقط. أمَّا هنا فيدفع المَجْعُولُ له مقابل [ ثمن السلعة أو رسوم الاشتراك] ثم يتربص حتى يأتي بالمستهلك فيدفع له

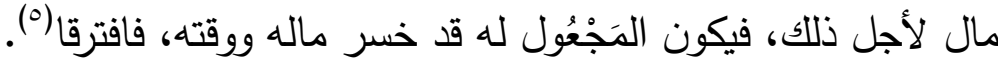

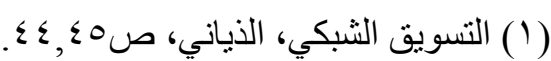

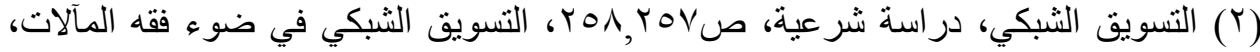

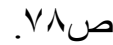
كما اتفق الفقهاء على أن الوكالة بأجر مجهول جهالة فاحشة تؤدى للمنازعة باطلة، وتباينت

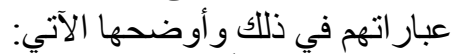

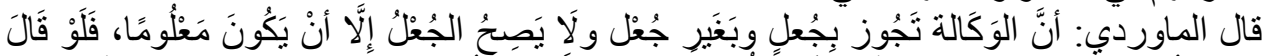

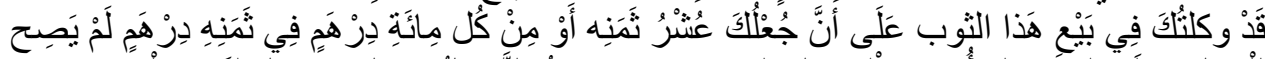

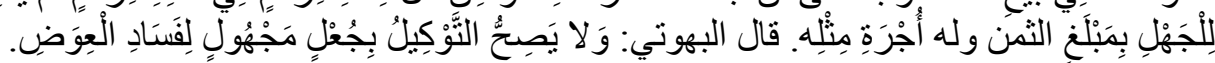

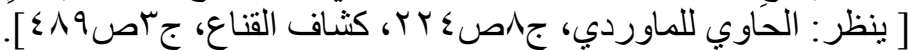

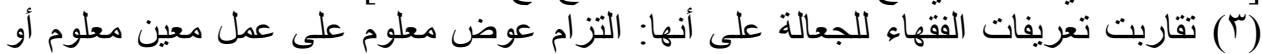

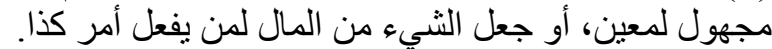

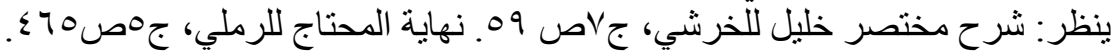

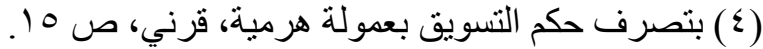

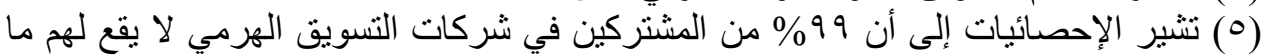

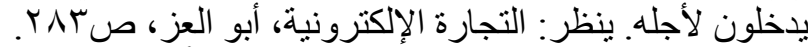

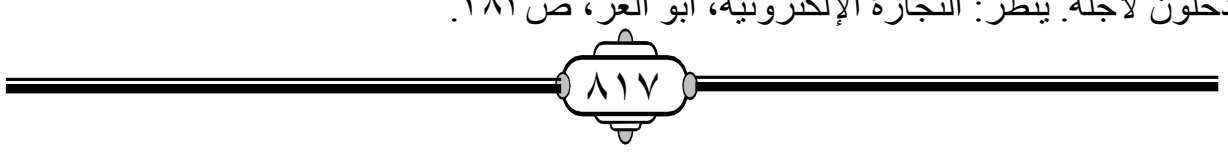


وبعبارة أخرى: ففي الجُجعالة يُقَدِم الجَاعِل المَجْعُول إن وَفَّى المَجْعُولُ لُه بشروطه(')، وفى التسويق الشبكي المتسلسل النشاط والمتنامي لا توجد نهاية لهذا

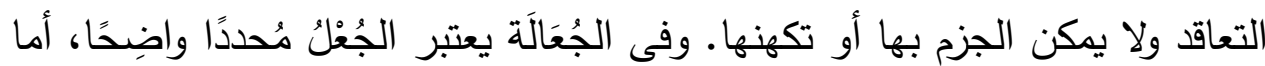
في التسويق فإن المتعاقد لو فشل في استقطاب الآخرين أو أقل من المحدد له وفق نظام الشركة فإنه لا ينال شينًا، وهي محتملة في عقد التسويق ليست محددة مقطوع

الثاني: أنَّ هذه الاحتمالات الواردة في عقد التسويق تجعله قائمًا على الغرر وجهالة المقابل، والجعالة متى تلبست بالغرر وجهالة المقابل بطلت(؟). ولا تكاد يقتصر الغرر على صورة واحدة وهو هنا جهالة العاقبة. قال القرافي: الغرر: هو القابل للحصول وعدمه قبولًا متقاربًا وإن كان معلومًا (๕) (1) قال ابن تيمية: والغرر هو : المجهول العاقبة(ه). ثم قال: وأما الغرر فإنه على ثلاثة أنواع: إما المعدوم، وإما المعجوز عن تسليمه، وإما المجهول المطلق، أو المُعَين المجهول جنسه أو قدره(؟).

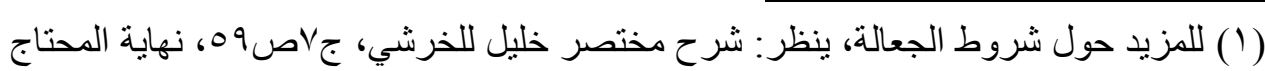

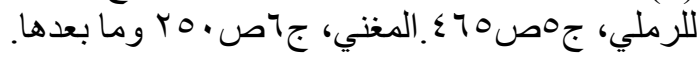

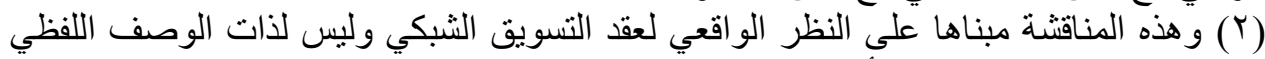

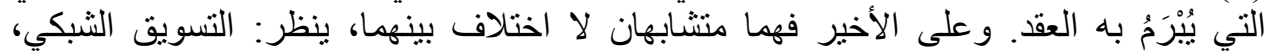

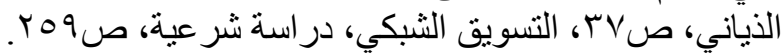

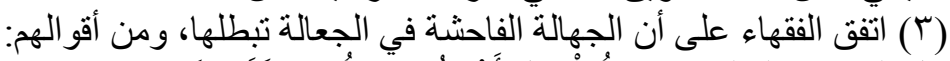

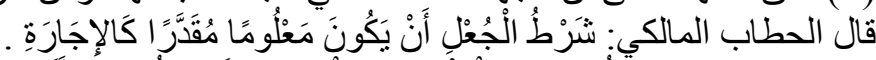

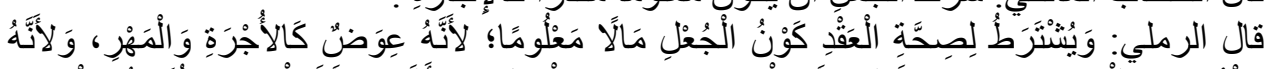

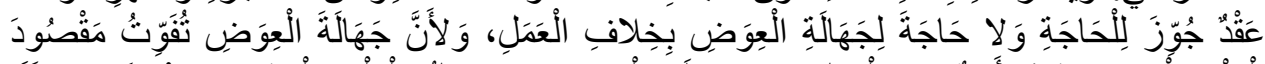

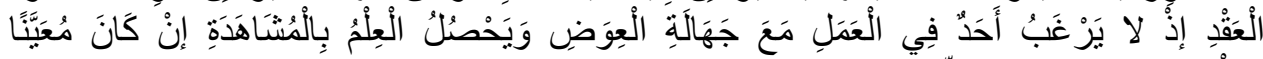

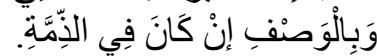

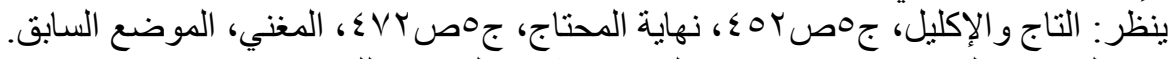

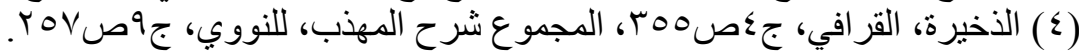

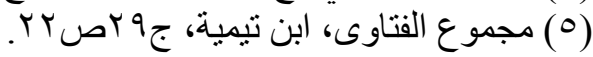

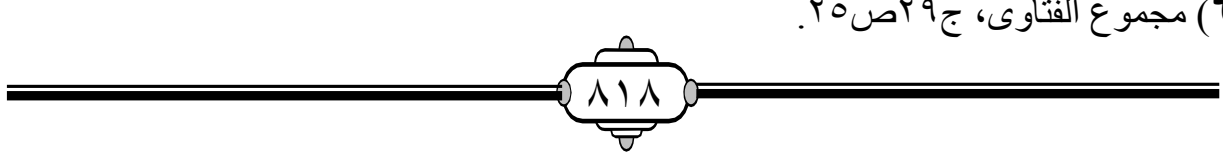




\section{التسويق الثبكي إثكالياته ومعالجاته الفقهية}

الثالث: يشترط في عقد الجعالة عدم استفادة الجاعل جزءًا من عمل العامل لذا أوجب جمهور الفقهاء حقًا للعامل في الجعالة إن انتفع بجزء عمله صاحب الجعالة. وهذا خلافًا لما يحدث في التسويق الشبكي ففي حالة عجز العميل عن إيجاد مشتركين جدد · 1 أشخاص مثلًا فإنه لا يستحق شينًا، ولا يطالب الشركة بالمبلغ الموعود حتى يكتمل العدد، بينما تستفيد الشركة من الأعضاء الذين أتوها من

طريقه، ومن سيأتي من طريقهم (1). هـ أن التسويق الشبكي من قبيل الإجارة وأن المُسَوِق أجيرٌ لدى الثركة يقوم

بعمل مشروط مقابل أجرة، والإجارة جائزةُ شرعًا فكذا عقد التسويق الشبكي (؟). ونوقش ذلك: سلمنا بأن الإجارة جائزةٌ غير أنَّ عقد التسويق الشبكي يختلف

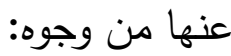

أولًا: أن الأجرة معلومة في عقد الإجارة بينما مجهولة محتملة في التسويق الشبكي حيث لا يعرف المُسَوِق إلى أن ينتهي به الربح فكان الربح مجهول. والثاني: أن الأجل في الإجارة معلوم، وفي التسويق الثبكي ليس بمعلوم للطرفين معًا؛ فالمُسَوِقِق لا يعلم متي ينتهي العقد مع الشركة، فإن كان الأجر والأجل مجهولان جهالة فاحشة فهذا مما يوجب بطلان العقد كما في الإجارة. T- أن التسويق الشبكي قائمُ على منتج حقيقي ورغبة حقيقية من البائع والمشتري في إتمام الصفقة، وفى التسويق المباشر متى وُجدَ المنتج ورغبة الأطراف في البيع أو الشراء صح العقد فكذا هنا.

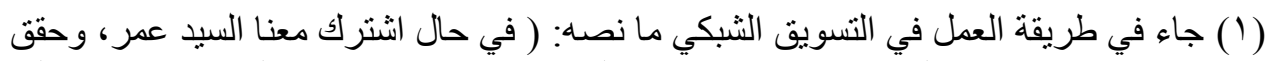

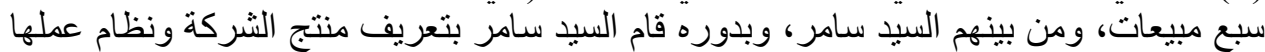
لعشرة أشخاص من معارفه، في هذه الحالة يتم تقبيض السيد سامر شيك بقيمة ( . . 9 و) ويتم إرسال

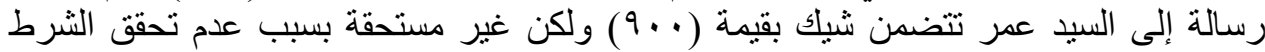
الواجب و هو أن يقوم بالتعريف لعثرة أشخاص وليس لسبعة). ينظر: التسويق الثبكي، الذياني،

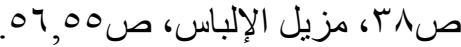

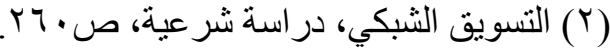




\section{التسويق الشبكي إشكالياته ومعالجاته الفقهية}

ونوقش ذلك بالآتي: أن المتتبع لعقد التسويق الشبكي والترويج له يرى أنَّ العبرة لا بالمنتج في شيء، وإنما إظهار العوائد والأرباح الراجعة للمشتري وإظهار هيكل ونظام الربح لاخوله فيه هو أساس العلاقة ، ومن ثمَّ فالمنتج إن وجد فهو لضرورة الدخول في النظام حتى تضمن الشركات ربحها لاحقًا إن رجع المسوق عن استقطاب الآخرين. ومعلوم فقهًا: أن العبرة في العقود بالمعاني لا بالألفاظ

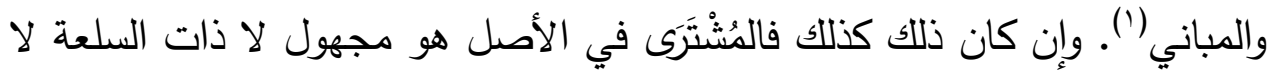
يُعلم متى يستعيد المشترى ربحه ورأس ماله وأنه يدفع لا ثمنًا للسلعة، وإنما رأس مال للاستثمار مجهول، والعائد له مجهول وهذه المجهولية تستلزم التحريم كسائر العقود في المضاربة مثلًا (ץ).

القول الثاني: ذهب بعض الفقهاء المعاصرين إلى جواز التسويق الشبكي استنادًا على ما سبق من أدلة، لكنهم وضعوا ضوابط لا تخرج عن جملة ما اشترطه الفقهاء في كل المعاملات، وربما دعاهم لذلك معالجة ما اشتهرت به هذه المعاملات من آثار وسلوكيات سلبية، وتتمثل هذه الضوابط في الآتي: الأول: تجرد المعاملة والعقد عن الغش والكذب والتدليس والغرر . الثاني: أن لا يتعرض عمل الثركة مع القوانين المنظمة لحقوق المستهلك والاستثمار المال وغير ذلك.

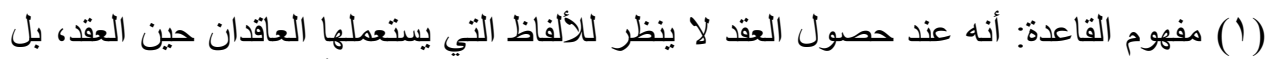

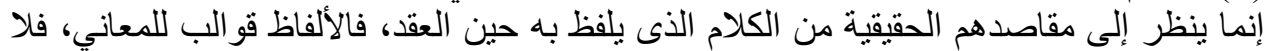

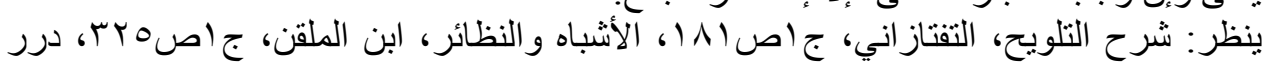

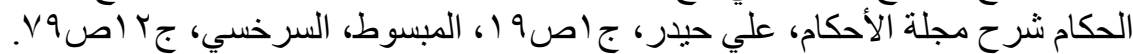

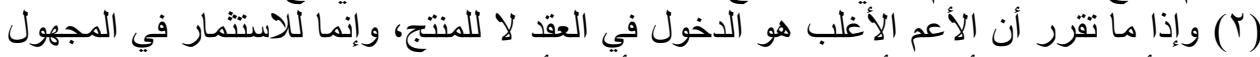

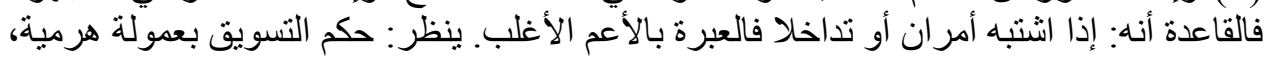

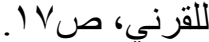
ينظر في مفهوم القاعدة: الأشباه و النظائر، السيوطي، صك 9، درر الحكام، علي حيدر، صا ــ

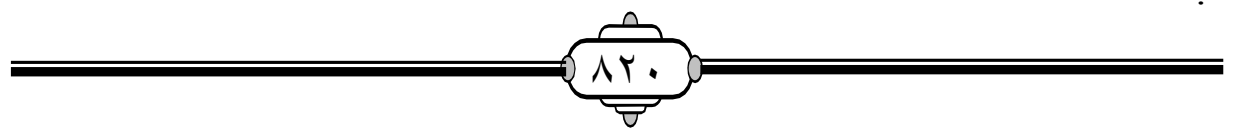




\section{التسويق الشبكي إشكالياته ومعالجاته الفقهية}

الثالث: أن يكون النشاط مشروعًا من حيث نوع السلعة، والخدمات المقدمة،

$$
\text { وإجراءات وطرق الحصول عليها('). }
$$

القول الثالث: ذهب جمعٌ من الفقهاء المعاصرين إلى القول بحرمة التسويق

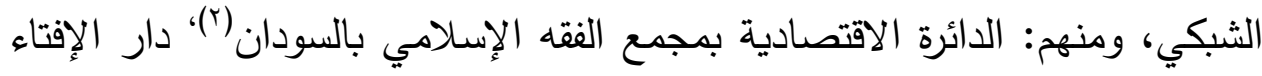

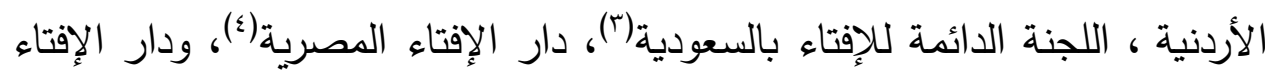

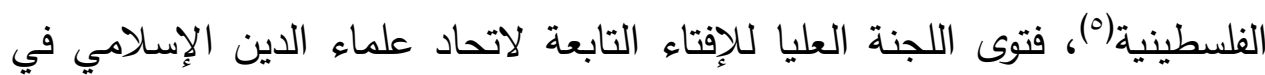

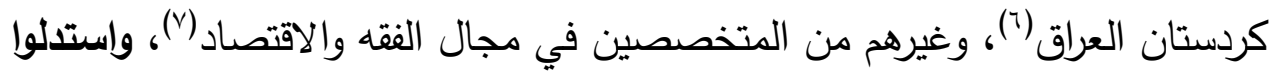

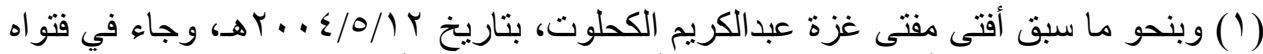

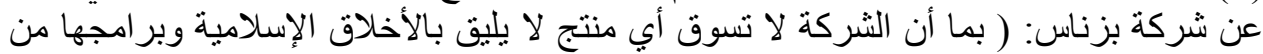

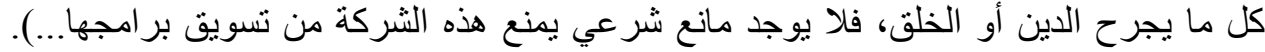

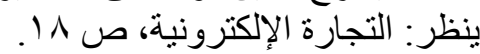

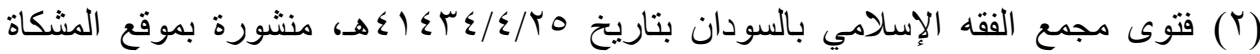
https://www.almeshkat.net/fatwa الإسلامية فئرية وأيضاً:

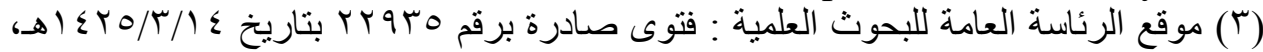

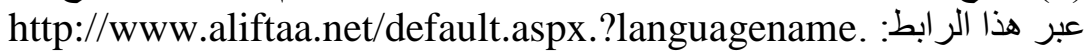

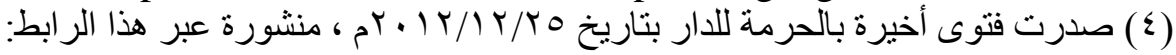
http://www.dar-aliftaa.org/viewfatwa.aspxid (0) وقد جاء فيها: وبناء على ما تقدم ذكره فإن التعامل مع هذه الثركة حرام شر اعًا. ينظر: الموقع الرسمي : (7) فتاوى اللجنة العليا للإفتاء في إقليم كردستان، إصدار اتلات اتحاد علماء المسلمين في كردستان،

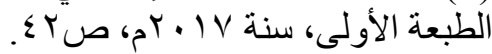

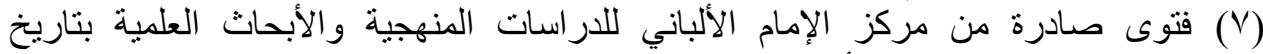

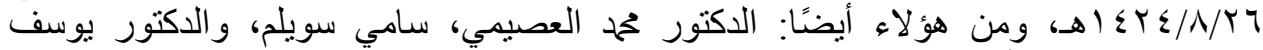

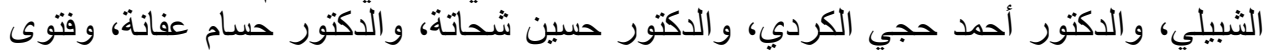

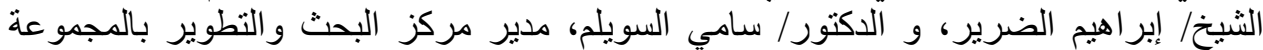

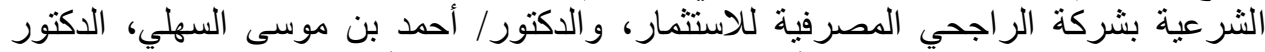

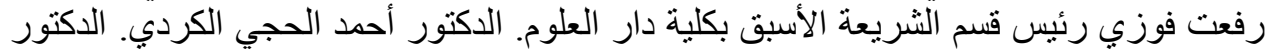

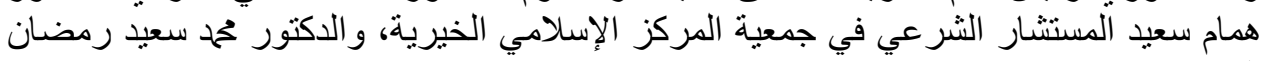

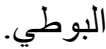

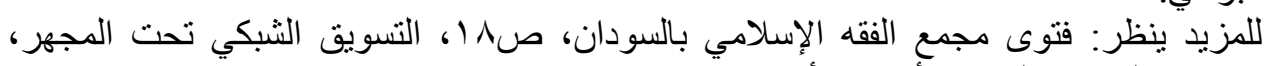

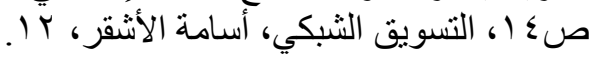


اـ أن هذه صورة من صور الربا المحرم شرعًا'(')؛ وبيان ذلك: أن المقصود لا ذات المنتج، وإنما هو الاخول في عملية الاستثمار، وهذا الغرض هو واقع حال المشترين والمسوقين للشركة حيث يظهرون العوائد والأرباح المتوقعة وربما لا هال يتطرقون للمنتج أصلًا، وإن كانت العبرة في العقود بمعانيها، وأكد الواقع ذلك مِراراً ، وهو المعلن على صفحات شركات التسويق. فإن سلمنا بهذه المقدمة فتكون الصورة

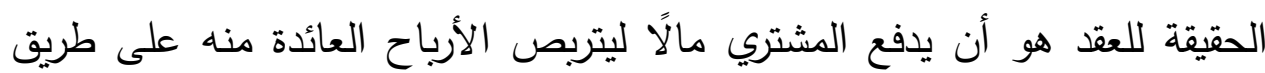
المضاربة أو الاستثمار واضعًا المنتج بينه وبين الشركة قصد أو لم يقصد، فما حكم هذه المعاملة شرعًا.

والجواب أنه حيلة ربوية محرمة(؟)، وبيان ذلك: بأن المشتري يدفع نقودًا قليلة

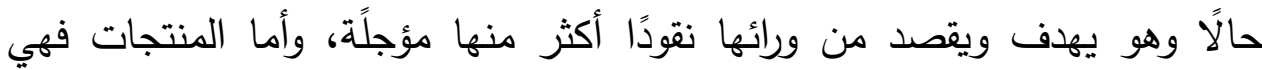

ينظر: ينظر : ينزر : وأيضّا: وttp://www.meshkat.net/assay/biznasfatwa2.htm و وأيضاً:

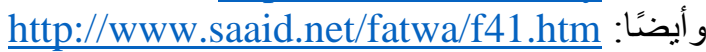

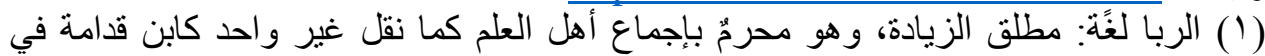

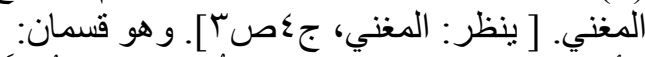

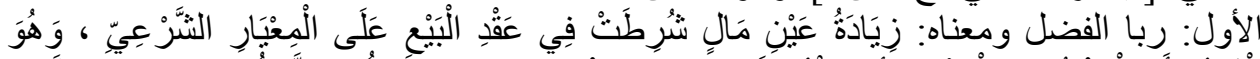

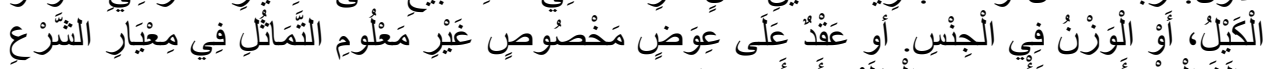

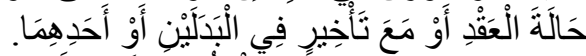

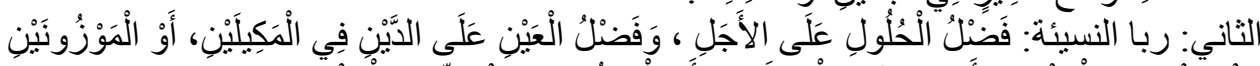

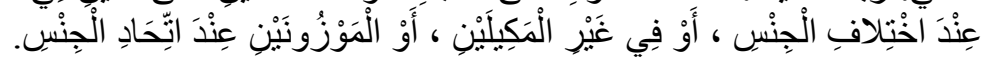

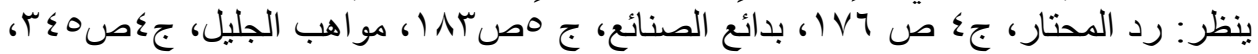

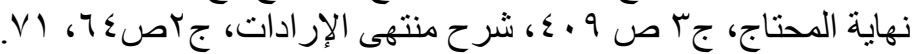

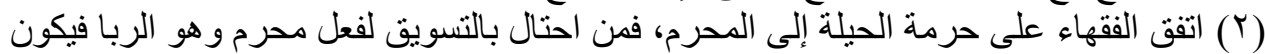

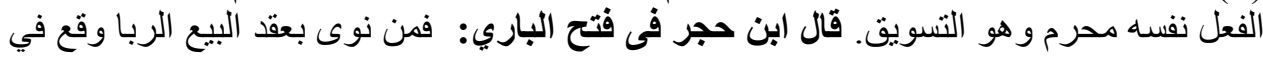

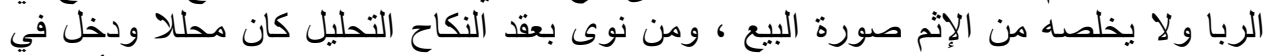

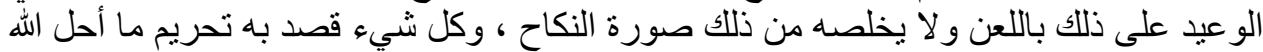

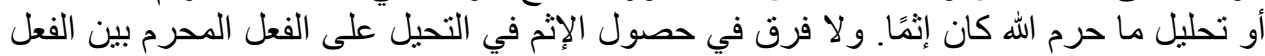

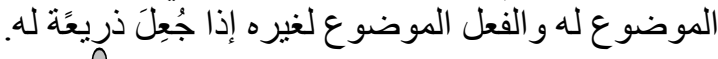


ليست مقصودة لذاتها، وإنما لتُحَقِق للشركات عدة أهداف منها: إعطاء واجهة سلعية مقبولة لتُُنْي عليها الترخيص النظامي لمزاولة النشاط في الدولة، ولمراعاة الحالة النفسية للمشتركين وإيهامهم بأنهم يزاولون عملاً منتجاً ومفيداً (1).

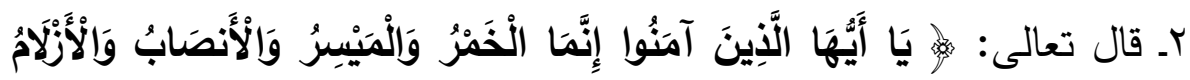

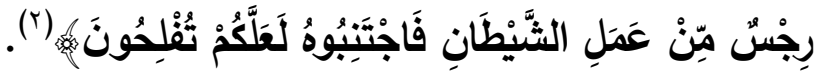

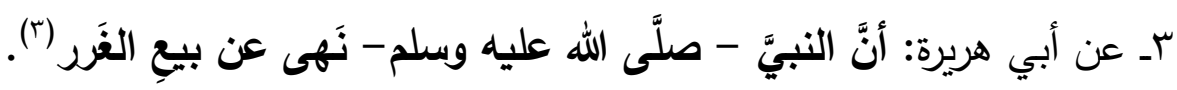
وجه الالالة من النصوص: أن المقامرة(£) والميسر والغرر(') محرٌ شرعًا، والتسويق الشبكي لا يخلو منهم حيث يدفع المتعامل في البداية ثن السلعة اضطراراً

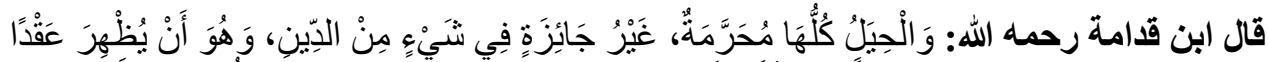

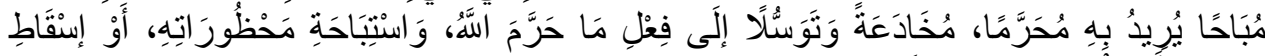

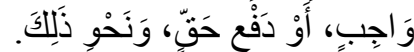

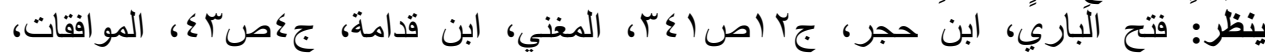

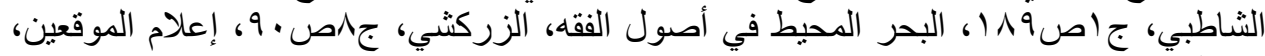

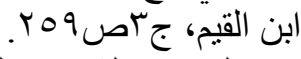

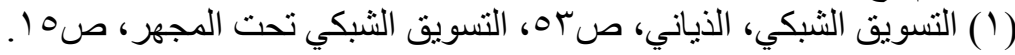

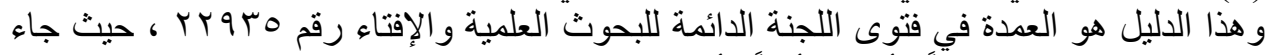

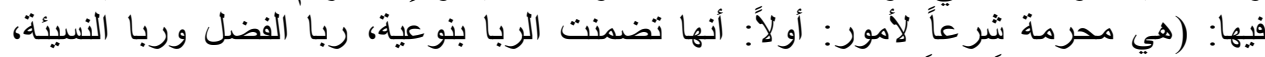

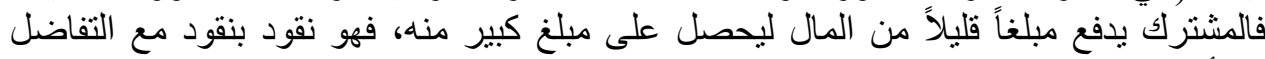

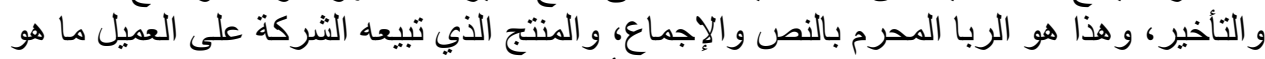

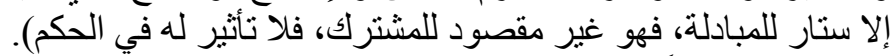

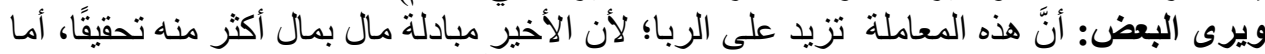

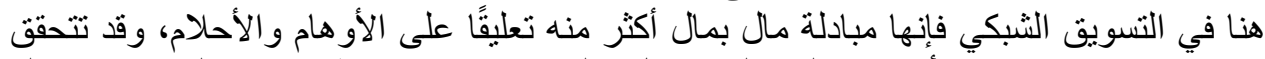

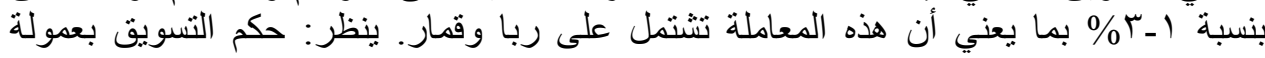

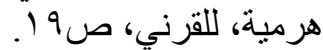

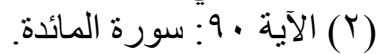

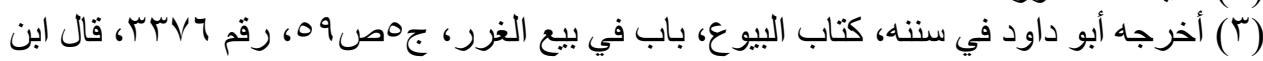

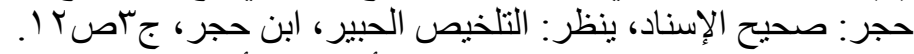

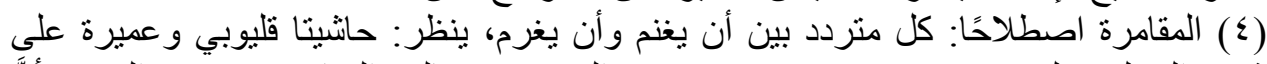

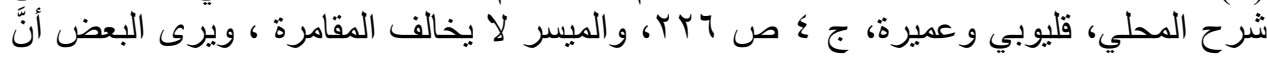

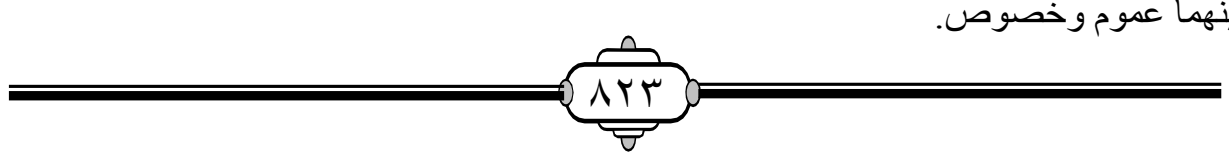




\section{التسويق الشبكي إشكالياته ومعالجاته الفقهية}

راجيًا تحقيق الربح والكسب بدخوله في دائرة الإغراء، فيكون احتمالية الربح والكسب مجهولة واردة على سبيل المقامرة المحرمة شرعًا، أو يقال: بأن المسوّق الذي دفع المال لا يضمن الإتيان بمن يشتري عن طريقه، وخاصة في المستويات الأخيرة من الشبكة. بل رأى بعض لخبراء الاقتصاديين أن مستوى الخسارة في التسويق الشبكي أعظم منها في القمار (r).

ومدار القمار: على احتمالية الغنم والغرم، وصورة ذلك: في التسويق الشبكي أن العميل الأول يدفع مبلغًا من المال [ قيمة السلعة كستار] وأمله وطمعه على أن يدر ذللك أرباحًا طائلة عند قيامه بالتسويق لمنتجات الشركة، وهذا الأمل غالبًا ما يصطدم بصخرة الواقع ويخسر المساهم، وقد يحدث أن يستفيد عدد قليل جدًا، كما هو الحال في كل صور القمار المتنوعة، حيث تربح فئة قليلة ليكون ذلك مغريًا

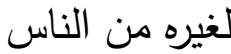

للانكباب على هذا القمار (r). ويُعدُّ الاستدلال على الحرمة بالمقامرة والميسر والغرر هو أقوى الأدلة وأوجهها، وذللك لانطباق مفهوم القمار والميسر والغرر عليه؛ لأن المشترك لا يدري هل ينجح في تحصيل العدد المطلوب من المشتركين أو لا، كما لا يدري المشترك حين

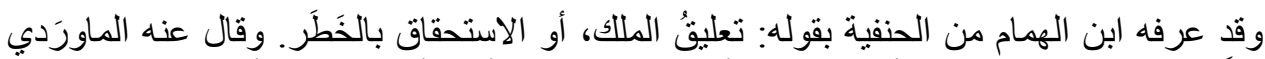

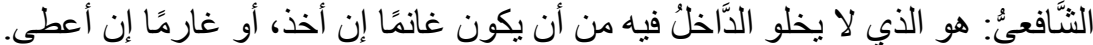

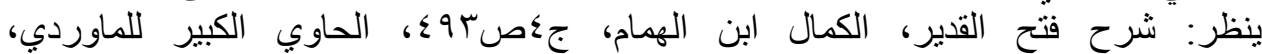

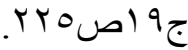
(1) الغرر اصطلاحًا: الغرر ما يكون مجهول العاقبة لا يدرى أيكون أم لا، ينظر التعريفات،

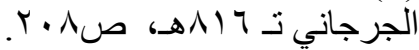
(Y) و هذا الدليل هو عمدة بعض اللجان و والباحثين القائلين بحرمة التسويق الثبكي.

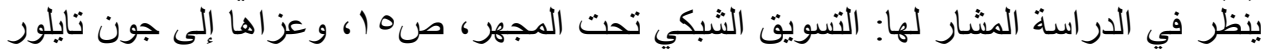

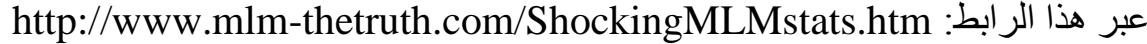

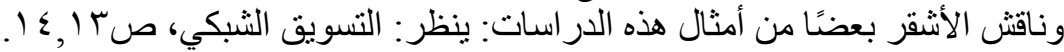

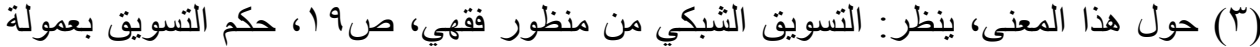

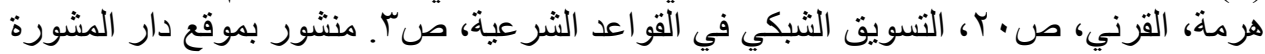
للافتصاد الإسلامي، Www.darelmashora.com 


\section{التسويق الشبكي إشكالياته ومعالجاته الفقهية}

انضمامه إلى الهرم هل سيكون في الطبقات العليا منه فيكون رابحاً أو في الطبقات الدنيا فيكون خاسراً، وإن كان الواقع أن معظم أعضاء الهرم خاسرون إلا قلة قليلة

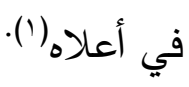

فإذا قال قائل أين القمار؟ وأين الغرر؟ والسلعة موجودة وفيها منفعة للمشتري،

$$
\text { ومن ثَّ لا يُعدُّ خاسراً إذا توقف نظام الشركة، فالجواب: }
$$

أن وجود السلعة شبهة اتخذت ذريعة لأهداف يصبون إليها، وهي شبهة أول من

ينقضها المسوّقون والعاملون في هذه البرامج أنفسهم، جاء في موقع أحد الشركات: المطلوب مراعاة أهمية التعليم والتدريب في هذا العمل، فمن يفهم هذا العمل على أنه مبيعات فقط، سيفشل فشلاً ذريعاً.

بل إنَّ بعض المشاركين قد يشتري السلعة عشرات المرات مع أن السلعة الواحدة

تفي بغرضه، فهل هذا شأن من يريد أن يستفيد من السلعة؟(؟) ورُدَّ على ذلك: بأنه لا مانع شرعًا أن يستأثر قلة بالربح دون الآخرين إذا كان

العقد متوافر الثروط، وهناك سلعة حقيقية تُقصد بالثراء (r). وأجيب عنه: بأن العقد قد اشتمل على محاذير شرعية، إضافةً إلى أن المنتج

\section{ليس مقصودًا لذاته}

بل لما يأمله ويخلفه من أرباح وعوائد، ومن ثمَّ فقد جُعلت السلعة حيلة للربا، ونتيجة التسويق أن الطبقات السفلى تُعطى أموالها للطبقات العليا على أمل أن يأتي

دورها(§)

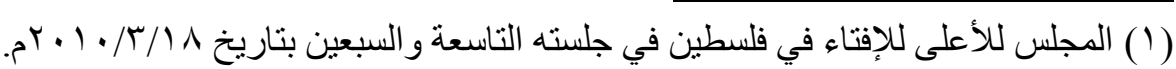

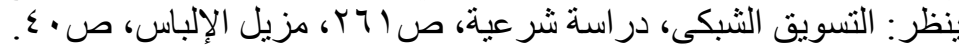

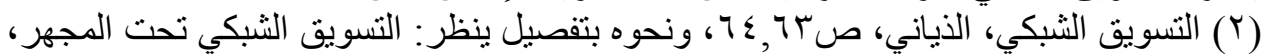

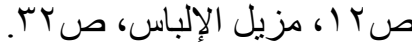

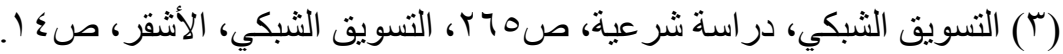

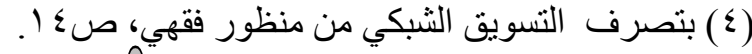




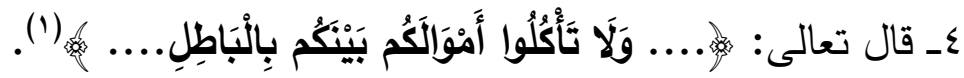

وجه الدلالة من الآية: أن الله تعالى شأنه حرم أكل أموال الناس بالباطل أي

بدون سبب شرعي معتبر، والمقصود بأكل الأموال بالباطل هنا: إنما هو فئة المتربعين على قمة الهرم التسويقي، والذين يجنون الأرباح الكبيرة على حساب آمال وإغراء المستهلكين من فئة الفقراء واستنفاذ قدراتهم المالية في عملية وهمية للكثيرين

منهم.

ويمكن القول: بأن هذا النوع من البرامج التسويقية لا تتمو إلا في وجود من

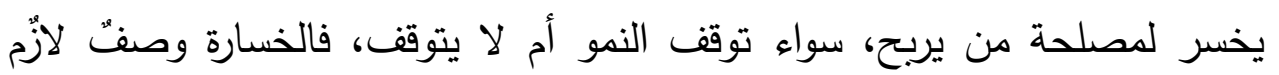
للمستويات الأخيرة في جميع الأحوال، وبدونها لا يمكن تحقيق العمولات الخيالية للمستويات العليا، والخاسرون هم الأغلبية الساحقة، والرابحون هم القلة، أي أنَّ القلو كسبوا مال الأكثرية بدون حق، وهو ما نص على القرآن على تحريمه. كما أنَّ هذا النمط يسمى بـ [ التعامل الصفري] حيث ما يربحه البعض هو هون ما يخسره البقية(؟). هـ من المعقول: إنَّ المتأمل في ذات النظام التسويقي قد يلحظ أنه لا إشكال فيه من حيث اشتماله على بيع وشراء غاية ما اعترى التسويق الشبكي عقب نشأته من مفاسد بحيث أصبح حيلة لشركات كبرى لم تقصد ترويج السلع والمنتجات، وإنما قامت بتدريب العديد من العملاء على إغراء المستهلكين بالتربح والكسب السريع، وفى سبيل ذلك: لا تخلو الطريقة من تدليس تارةً وكذب تارةً ومبالغة تارةً أخرى، وبات ذللك السمة الغالبة على المعاملة، وتلك الآثار مجتمعة هي مناط الحرمة.

(1) (1) من الآية رقم 1 (1) سورة البقرة.

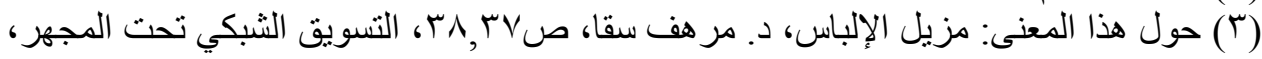

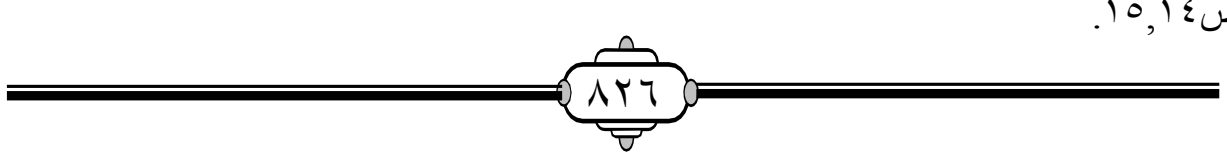


الفرع الثالث: الرأي المختار .

بعد عرض الأقوال الفقهية وأدلتها ومناقشتها يميل البحث إلى القول بحرمة التسويق الشبكي على صورته الحالية، وترجع أسباب التحريم للآتي: ا. قوة أدلة التحريم وخلوها من المناقشات والمعارضات. r ـ ضعف أدلة الجواز وعدم سلامتها من المناقشات. بـ يتبني القول بالتحريم العديد من المؤسسات الفقهية و الإفتائية أو البحثية يما يشير إلى النظرة التكاملية للموضوع، وهي بحسب نظامها ترجع في بناء تصور صحيح للنوازل المستجدة إلى الاقتصاديين والقانونيين وهما عمدةٌ في الكثف عن الآثار السلبية لهذه الأنظمة التسويقية . ع. القول بالتحريم يتفق مع المقاصد الثرعية، ومنها: حفظ المال، فالتسويق الشبكي بصورته الحالية يتعارض معه، فالإسلام أراد أن تكون الأموال وسيلة للاستخلاف، وحتى يحقق هذا الغرض شرع مبدأ الشفافية في المعاملات المالية، ويندرج تحته ضرورة تنظيم المعاملات على أسس الرضا والاختيار وقطع المنازعات، ولأجل هذا منعت الثريعة المقامرة والغرر؛ لأنها تؤدي إلى المنازعة، ولا ينكر أحدًا أن النزاع والخصومة بين العملاء الجدد وشركات التسويق باتت ظاهرة تم رصدها من قِبِل العديد من المؤسسات الرسمية(1). كما أنه يقود ويوجه الأموال إلى مجالات توظيف غير ضرورية وغير حاجية، وأحيانًا توجه الأموال إلى مجالات لا تدخل في نطاق الضروريات والحاجيات للمشتري ، وربما يستدين المشتري من أجل المكافأة وهذا يسبب خلاًا في توجبه الأموال إلى التتمية. كما أن هذا النوع من التسويق لا يحقق التتمية الاقتصادية من

$$
\text { (1) بتصرف من التسويق الثبكي بين الحلال و الحرام، نجلاء عبدالمنعم، صVوله }
$$


المنظور الإسلامي بل يحقق بيئة استهلاكية ومقنّعة تستتزف نسبة عالية من الأموال والجهود كان يمكن توجيهـا إلى مشروعات استثمارية تشغّل العاطلين (1). هـ القول بالتحريم يحمي المجتمعات من هدر القيم وتقطع العلاقات الاجتماعية، وبيانه: أن هذه الطريقة باتت ذريعةً إلى هدر القيم والأخلاق والسلوكيات، وأحيانًا يكذِب أو يُعَدِّم معلومات فيها تدليس وجهالة وكله مخالف للشرع(؟). كما أنَّ التسويق الشبكي يفسد العلاقات الاجتماعية، حيث يسعى منتسبوه لجعل علاقاتهم الاجتماعية مُحقِقَةً إضافَة ماليَة بانتظام الأقرباء في هذه الشركات ونحو

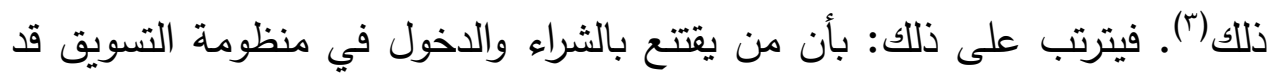
يخسروا جهودهم وأموالهم إذا لم يتمكنوا من استيفاء الشروط المعتبرة عند الشركات، وهذا يؤثر سلبًا على علاقاتهم بمن أقنعوهم من الأقارب والأصدقاء. ومعلوم أن الشريعة سدت منافذ التغرير والغش حفظًا للأمن الاجتماعي والاقتصادي معًا (؛). هـ كما أنَّ الآثار السلبية للتسويق الشبكي دفعت العديد من الأنظمة الغربية إلى تقنينه أو تجريمه، ومعلوم ان كل ما يؤدى إلى الإفساد في الأرض أو هدر الأموال

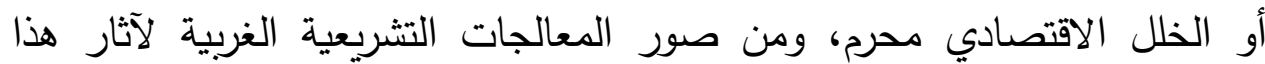
النظام السلبية ما يلي: ذهب المشرع الفرنسي إلى وضع شروط ثلاثة لكي يكون العقد مشروعًا تتمثل في: ( تعليق الامتيازات الموعود بها على كسب شخص واحد

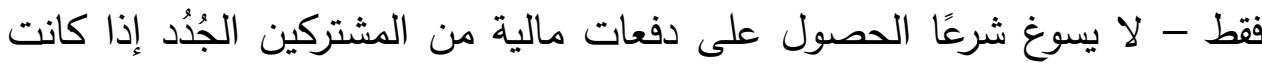
تصبُّ في جيبٍ واحد أو أكثر من المشتركين - يجب أن تضمن الشركة لبائع

(1) شبهات حول التسويق الثبكي، د. حسين شحاتة، وله أيضًا: على نفس موقع مقال بعنوان: إنما التسويق الثبكي محرم فاجتنبوه، منشور عبر هذا دالت الر ابط: Www.darelmashora.com (Y) شبهات حول التسويق الثبكي، د. حسين حسين شحاتة.

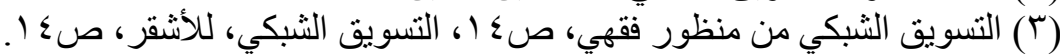

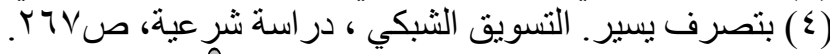




\section{التسويق الثبكي إثكالياته ومعالجاته الفقهية}

البضائع استعادة بضائعها غيرَ المِبيعَة لفترة سنة بعد الشراء مع تخفيض في السعر

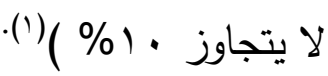

وقد حذرت وزارة التجارة الأمريكية من البرامج الهرمية، وتبين حقيقتها فتقول:( لا ل

تتعرض للحرق من قبل تنظيم هرمي، وتضع إرشادات لتجنب التنظيمات الهرمية: 1 - تجنَّبْ أيَّ خطة تعرض نسبة ربحية لجلب موزعين جدد.

r - احذر الخطط التي تطلب منلك إنفاق المال على قوائم باهظة الثمن. r - احذر الادعاءات التي تَعُْلْ بالمال مقابل استجلاب أعضاء جدد بدلاً من المبيعات التي تحققها أنت بنفسك.

ع - احذر الوعود المتعلقة بأرباح عالية، أو ادعاءات حول منتجات إعجازية. 0 - كن متتبهاً للمراجع التي يمدونك بها. 7 - لا تدفع المال أو توقع عقود عند حالات التعرض للضغوطات المحرجة من قبل المُرَرِّج. V - تأكد من جميع العروض التي تأتيك من خلال المنظمة الرسمية للتجارة، والنائب العام لمنطقتك؛ ولذا تشترط عدة ولايات أمريكية أن يكون عائد التسويق المباشر للمستهلك النهائي لا يقل عن • \&\% من إجمالي عوائد التسويق، بمعنى أن

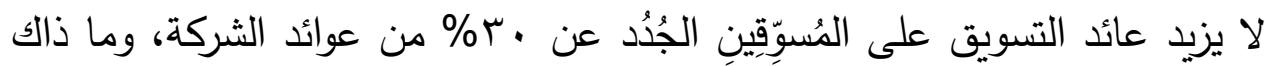
إلا تأكيداً للفرق بين البيع على المستقيد الفعلي من المنتج وبين البيع على من يريد الانضمام إلى هرم المسوقين (ז). وفي كندا أضافت الحكومة في قوانين الجرائم جزعاً خاصاً بتجريم كل فرد أو إن مجموعة تمارس نظام أهرامات الوهم، ويوضح موضع الشرطة الكندية أن ملايين

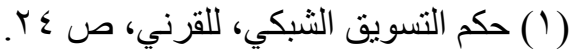

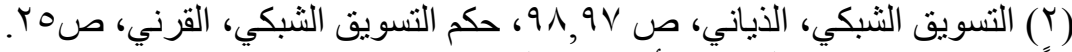
نقلًا عن: موقع وزارة التجارة الأمريكية على الإنترنت: (htt:/www.ftc/gov/bcp/conling/edcams/pyramid/index.htm) 


\section{التسويق الشبكي إشكالياته ومعالجاته الفقهية}

الدولارات قد جمعت من المشتركين الذين خسروا أموالهم، بينما فاز عدد قليل بكمية

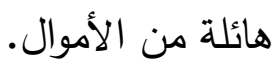

كما حذرت هيئة الأوراق المالية بدولة باكستان من التعامل مع بعض الشركات

الهرمية؛ لكونها تستخدم أساليب غير مشروعة وتحايلية وغير أخلاقية(' له كما أن وزارة التجارة الأمريكية رفعت دعوى ضد إحدى هذه الأنواع من الشركات تسمى سكاي بز

[skybizcom ]

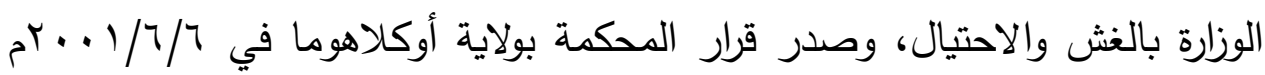
بإيقاف عمليات الشركة وتجميد أصولها تمهيدًا لإعادة أموال العملاء الذين انضموا إليها (r).

وبذلك التحول الكبير في موقف الأنظمة الاقتصادية الوضعية التي كانت منشأ هذه الطريقة في التسويق، والتي بدورها تحرص على تتمية روافد المال بما يؤكد خلوها من المنافع الاقتصادية، وأنها لا تتعدى أن تكون وسيلة لمكاسب شخصية، فضلًا عن هدر جهد الأفراد وأموالهم في غير فائدة اقتصادية خاصة أو عامة. ومن المقرر فقهًا: أن المصلحة العامة تقدم على المصلحة الخاصة(؟). فإن تعارضتا فتقدم المصلحة العامة على الخاصة. وبناء على ذلك الأصل: فإن ترتب على على التسويق الشبكي تتمية ثروات الأفراد على حساب مصالح الأمم والشعوب والدول فلا مناص من القول بمنعه جرياً على مقتضيات قواعد الشرع والعقل.

(1) (1) المر اجع السابقة، نفس المواضع، نقلًا عن: (http/www.spcp.gov.pk/other likns/biznasbiznas.com.htm)

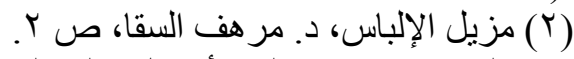

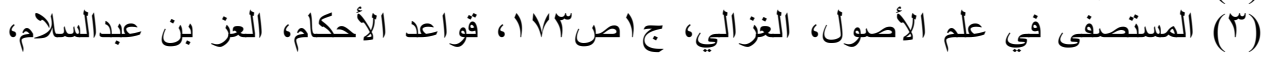

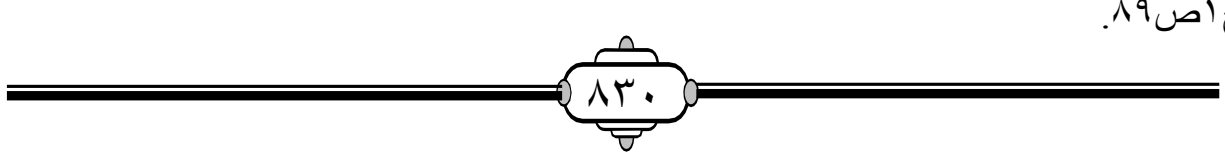




\section{المطلب الثاني: الآثار الفقهية المترتبة على التسويق الثبكي.}

بناء على الرأي المختار بحرمة التسويق الشبكي فإنه يترتب علي دخول البعض فى عملية التسويق من شراء للمنتج ودفع ثمنه المتقق عليه بعض الآثار الفقهية منها:

الأول: حرمة الشراء والتسويق لهذه الشركات والتكسب منها والترويج لأنشطتها؛

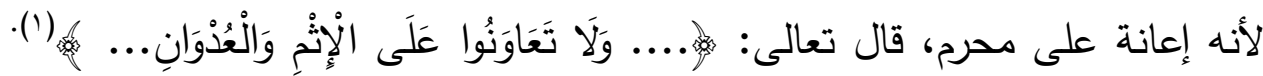

$$
\text { والقاعدة: أن الوسيلة إلى الحرام حرام(؟). }
$$

الثاني: يترتب على شراء المنتج الحق في الثمن لبائعه [ الشركة - المسوّق] ، والحق في قبض المنتج، وخلوه من العيوب، والرجوع بالعيب على البائع. الثالث: يحل لمشتري المنتج بيعه لغيره خارج منظومة التسويق الشبكي؛ لأنه تََلَكَكَ عينه فيحق له أن يتصرف فيه تصرف المالك من البيع والهبة والعارية والإجارة وغيرها. 
المطلب الثالث: المعالجات الثرعية لإثكاليات التسويق الشبكي. ( مقترح في تصحيح الصورة الحالية)

المقصود بالإشكاليات هي مقتضيات التحريم أو هي: مجموعة الأدلة التي أُشكلت على القائلين بالجواز حال النظر في التكييف الفقهي للتسويق وتقرير الحكم الصحيح له. والمقصود بالمعالجة الشرعية هي البدائل المقترحة والممكنة نظرًا وتطبيقًا بحيث تتجنب أسباب ومقتضيات الحرمة. ويمكن القول: أنه بعد تأمل أسباب الحرمة المُلََزمَةَة لأنشطة شركات التسويق الشبكي يمكن طرح هذه المعالجة بحيث يلزم من توفرها القول بالجواز ، ومن ذلك: أولًا: عدم اشتراط شراء المنتج، وهو شرط الشراء مقابل الدخول في منظومة التسويق الشبكي، وبهذا يحق لكل مسوّق أخذ عمولة على تسويقه واستقطاب العملاء، وهذا من السمسرة الجائزة أو الجعالة أو وكالة بأجر ('). ثانيًا: أن يكون المنتج المزمع بيعه مشروعًا وذا قيمة ليساهم في إثراء البيئة الاقتصادية والاستهلاكية، ولا يترتب عليه هدر للوقت والمال وتفويت فرص التمية. ثالثًا: خلو الدعاية للشركات من المبالغات والتدليس وقوائم من عبارات الإغراء التي تعضد الغرر المنهى عنه شرعًا. ويستلزم ذلك التعريف بالمنتج ومعلوميته للمشترى خاليًا عن الجهالة الفاحشة، ووجب مراعاة الضوابط الشرعية بحسب كل نشاط أو سلعة.

رابعًا: تقنين أوضاع الشركات العاملة في الأسواق قانونًا، وثمرة ذلك: عودة المستهلك والمسوّق على الثركة بحقوقه المالية عند الحاجة لذلك، وإمكانية مقاضاة

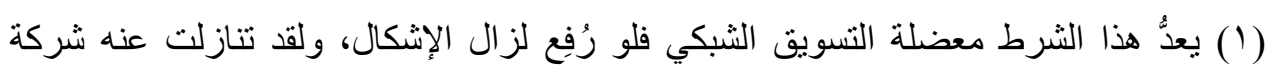
[questnet]

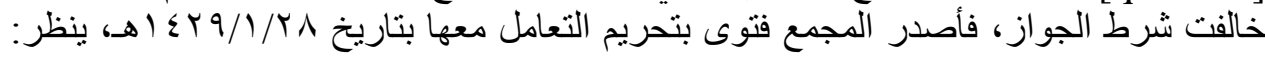

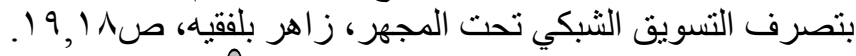

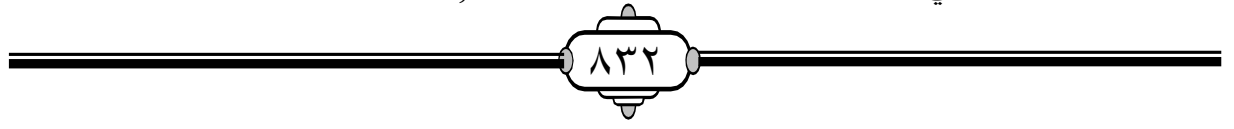


الشركات العاملة، فلقد تواتر عمل الشركات دون مقرات لها في بعض البلدان العربية بما يعني أن يتنازع المشتري مع المسوّق بعيدًا عن الشركة وهي صاحبة المنتج أو مصدرن.

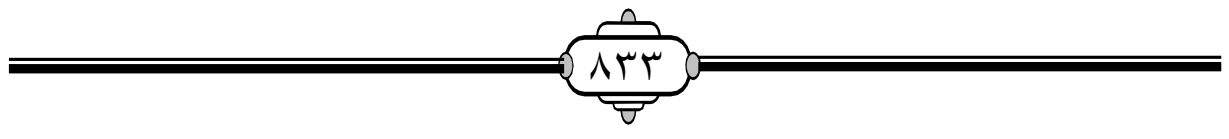




\section{الخاتمة}

بعد تتاول مفهوم التسويق الشبكي، والسمات العامة المشتركة بين الشركات العاملة في مجالاته، وعرض الاتجاهات الفقهية المختلفة حول حكمه، وآثاره الفقهية؛ فإن البحث قد انتهى إلى جملة من النتائج والتوصيات وهي: أولاًا: النتائج

اـ أن مفهوم التسويق الشبكي عامة لا يختلف بتعدد مسميات الشركات العاملة فيه، وأن هذا التتوع أحد حيل المسوقين والمستثرين؛ لإظهار الاختلاف بينها وبين غيرها، وليس في الحقيقة ثمة اختلاف. r. أن قصد تغيير الأسماء من حينٍ لآخر ناتج عن إصدار فتاوى ودراسات تطبيقية على بعض الشركات فارتبط الحكم بها - بحسب زعمهم - في ذهن المستهلك فكان في تغيير أسماء الشركات وسيلة لاستقطاب الجماهير بعيدًا عن التخوف من الحرمة؛ ولذلك حرص البحث على عدم التعرض لأسماء الشركات؛ له ليقى الحكم متسعًا لجميع الشركات المشتملة على هذه السمات المشتركة أو بعضًا من منا.

بـ إنَّ تغيير الأسماء من حين لآخر مقصودُ حتمًا؛ لأنه لا يمكن لشركة أن تصمد

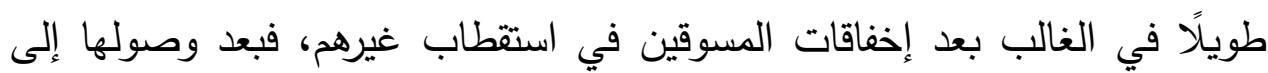
درجة العجز تحاول العودة للنشاط في ثوب جديد يعيد لمسوقيها القدرة على الجذب والإغراء، وضمان رجوع العوائد وتحقيق الأرباح مرة أخرى. عـ التسويق الشبكي يتسم في الجملة بـ ( ضرورة شراء المنتج - توظيف غير محدود للعملاء - الأكثر ربحًا للمتقدم عن المتأخر - عدم قصد المنتج - الدخول للنظام عبر العملاء القُدامى). ๑ـ إنتهى البحث إلى حرمة التسويق الشبكي من منطلقات شرعية واقتصادية واجتماعية وأخلاقية وأمنية.

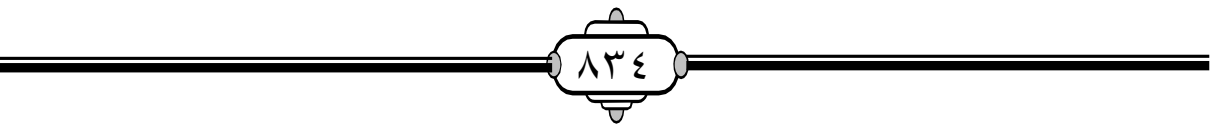


جـ. يميل البحث إلى عدم عرض الخلاف الفقهي على عموم المستفتين في هذه المسألة، وإنما يظل أكاديميًا أو بحثيًا حتى يكتمل النظر المؤسسي فيه أو يستقر؛ لأن الخلاف المشار له جاء قاصراً على استيعاب الصورة الحقيقية للتسويق، وحتى الهى من وضع شروطًا تبين له أن الشركات لا تحققها، ثم إن عَرْض الأمر كأنه مختلف فيه يجيز لذوى النفوس الضعيفة وللشركات العمل بمقتضى الحل ترويجًا لنشاطها. وفى رجوع دار الإفتاء المصرية وسحب التراخيص من قِبل الدائرة الاقتصادية لمجمع الفقه الإسلامي بالسودان وغيرهم من الباحثين خير دليل.

\section{ثانيًا: التوصيات}

' _ عدم تَعَجُّل المفتيين والمشتغلين بدراسات النوازل عبر المؤسسات والمواقع في إصدار فتاوى يتكئ عليها أصحاب المطامع والمقاصد السيئة؛ ليجعلوا من مادتهم الثرعية محتوى دعائي أو تسويقي، كما حدث في تعجل بعض المؤسسات بالإفتاء بالحل ثم رجعوا عن ذللك، ولم يأخذ الرجوع مثل ما أخذت الفتوى من الذيوع والانتشار وذلك؛ لأن المسوقين عمدوا لنشر فتاوى الجواز ترويجًا لشركاتهم وأخفتوا في نشر فتاوى الرجوع فكانت الفتوى مصدرًا تعتمد عليه خطط التسويق • r لـما سبق يجدر بالمفتيين والباحثين التكامل حول القضايا ذات الصلة بالفروع العلمية غير الفقهية كالاقتصاد. فمعلوم أن الآثار الاقتصادية السلبية للمعاملة قد يصل بها للحرمة، ولَمَّا كان الفقيه غيرَ مختصٍ بذلك وجب عليه أن يرجع لغيره تكاملًا بينهما، ولا يمنع أن تتكامل وتتشارك البحوث للوصول لوجه الحق تعبدًا لله وإحسانًا في العمل.

وقد جاء في بعض البحوث التي تناولت الموضوع ما يشير إلى هذا المعنى: فقد عُرِضت على بعض الفقهاء فأفتى بجوازها بشرط أن تكون منتجات المُنشأة حلالاً،

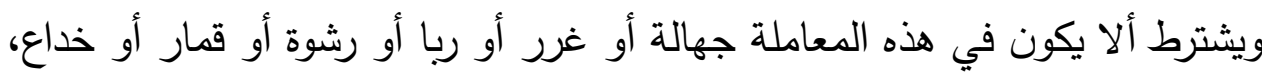

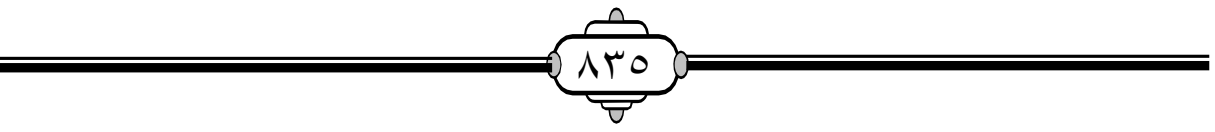




\section{التسويق الشبكي إشكالياته ومعالجاته الفقهية}

وكنت أتمنى أن لا تكون الفتوى على هذه الشاكلة، إذ كان على المفتي أن يقول لا أدري بسبب عدم تمكنه من فهم المعاملة (1). والواقع أن نِسَبَ المشاركات في البحوث العلمية النظرية قليلة بل تتعدم في بعضها وما ذلك إلا لعدم وجود ثقافة العمل المشترك أو الفريق العلمي، وعدم دعمها في الدراسات العلمية الأولية للطلاب ومن ثمَّ افتقدوا القدرة على القيام بها فيما بعد. والتوصية: بأنَّ كل بحثٍ له شق مغايرٍ للتخصص الدقيق للباحث الأصيل أن يتشارك فيه باحث في فرع التخصص الآخر إلزامًا لتحكيمه وقبول نشره. rـ_ الوقوف على النظام الأساسي لأمثال هذه الشركات ومثيلاتها حال التعرض للحكم عليها؛ لأن الأخذ من المستفتي وإن كان هو مقدمة الفتوى ومبدأها غير أن النال ذللك يناسب عصور التَّين وذيوع الوازع الديني وتوفره. أما في العصور الحديثة

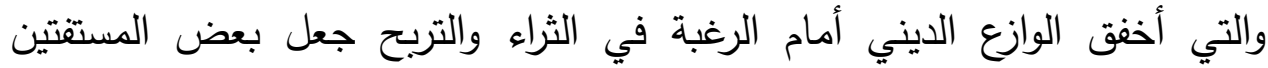

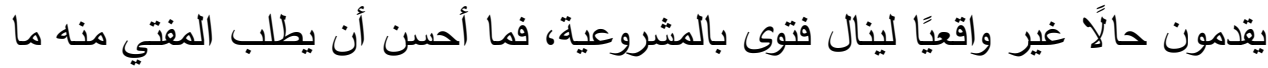
يؤكد صدق كلامه مثل النظام الأساسي للشركة، ونماذج من العقود المبرمة بين الثخص والثركة وأمثالها عقود التمويل المالية والمصرفية. ○_ تقديم البدائل الشرعية للمعاملات المحرمة - لا سيما - لو كانت الحاجة لها ملحة إنقاذًا للمجتمعات العربية والإسلامية من الحرام، وعدم ترك الأفراد أداة للاستقطاب الدحرم، ولنا في تجرية المصارف الإسلامية أنموذجًا، ففي الوقت الذى النى حرم فيه أهل الاقتصاد التسويق الثبكي وأظهروا لنا مساوئه لم يقدموا نموذجًا بديلًا متكاملًا يحقق الرغبات، ويعالج البطالة، وينهض به الاقتصاد جمعًا بين المصالح

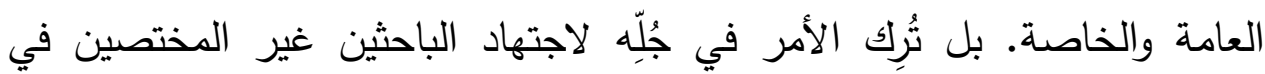

$$
\text { https://www.aliftaa.jo: (1) موقع دار الإفتاء الأردنية عبر هذا الرابط: }
$$




\section{التسويق الشبكي إشكالياته ومعالجاته الفقهية}

الاقتصاد، ولا يمكن لصورة أعَّ مقترح أن تتجح من وجهة النظر الفقهية المجردة إلَّا

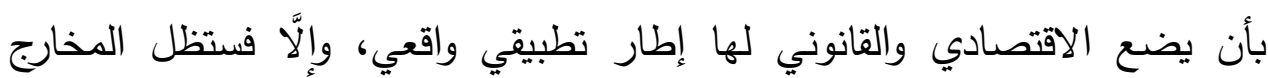

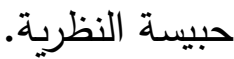

7 _ هذا المعالجات التي قدمها البحث تأتي في هذا السياق السابق ذكره، وهي أنها تتوقف على وضع الإطار التطبيقي من قِبل المختصين، وإنما يجتهد الباحثون في

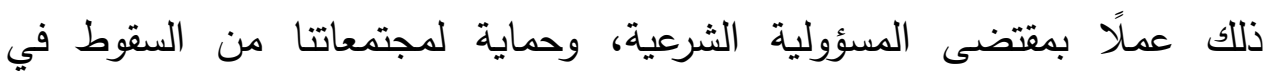

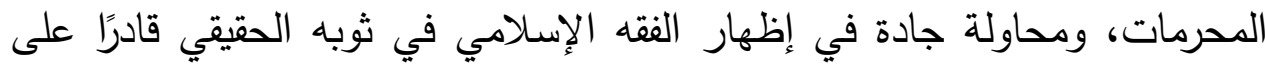
مسايرة النظريات والتعاقدات بضوابطه المتميزة. 


\section{مصادر البحث}

أولًا: القرآن الكريم.

ثانيًا: كتب الحديث والتخريج.

ا-سنن أبي داود، المؤلف: أبو داود سليمان بن الأشعث الأزدي السجستاني ،

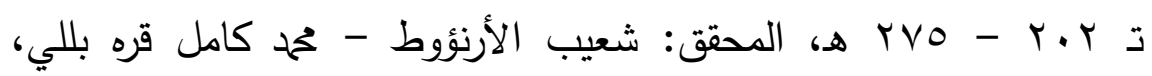

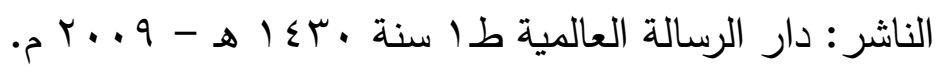

r-التلخيص الحبير في تخريج أحاديث الرافعي الكبير، المؤلف: أبو الفضل

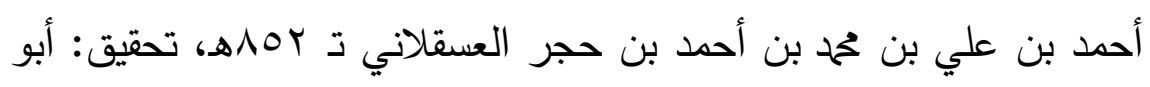
عاصم حسن بن عباس بن قطب، الناشر : مؤسسة قرطبة - مصر، طا

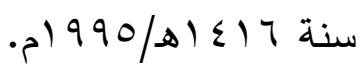

ب-فتح الباري شرح صحيح البخاري، المؤلف: أحمد بن علي بن حجر أبو الفضل العسقلاني الثافعي تريمهـ ، الناشر: دار المعرفة - بيروت،

$$
\text { . ) } r \vee q
$$

ثالثًا : كتب اللغة والمعاجم.

ع - مختار الصحاح، زين الدين أبو عبد الله عحم بن أبي بكر بن عبد القادر الحنفي الرازي ، تجا77ه، المحقق: يوسف الشيخ محمد، ط المكتبة العصرية

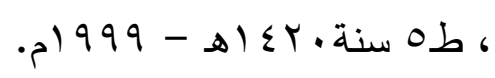

ه- لسان العرب، حمح بن مكرم بن على، أبو الفضل، جمال الدين ابن منظور

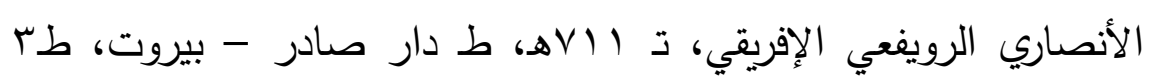

$$
\text { سنة عا (1) }
$$

7- المصباح المنير في غريب الشرح الكبير، أحمد بن حمح بن علي الفيومي ثم

$$
\text { الحموي، أبو العباس، ت . . Vه، ط المكتبة العلمية - بيروت. }
$$

V- كتاب التعريفات، المؤلف: علي بن حمح بن علي الزين الشريف الجرجاني ت

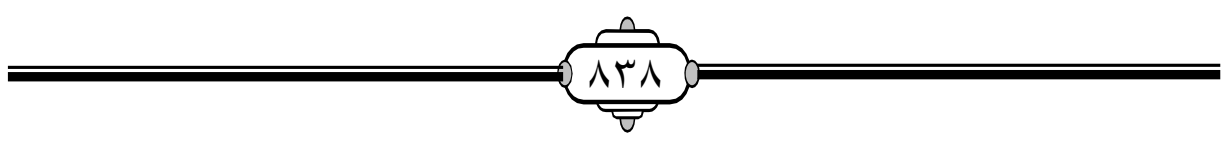


7 11/هـ، المحقق: ضبطه وصححه جماعة من العلماء بإشراف الناشر،

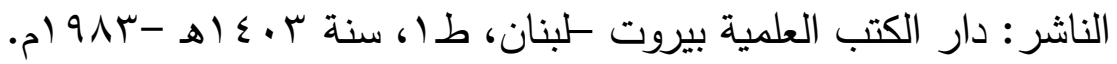
1-المعجم الوسيط، مجمع اللغة العربية بالقاهرة، ط دار الدعوة. 9-معجم لغة الفقهاء، المؤلف: حمد رواس قلعجي - حامد صادق قنيبي،

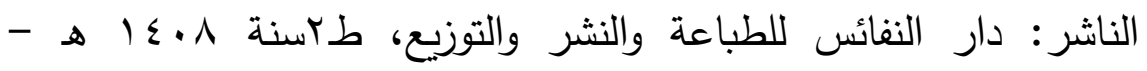

$$
\text { - Р) } 911
$$

رابعًا: كتب أصول الفقه والقواعد الفقهية.

• 1-المستصفى المؤلف: أبو حامد تحمد بن محه الغزالي الطوسي ت 0 .0هـ، تحقيق: حمح عبد السلام عبد الشافي الناشر: دار الكتب العلمية طا سنة

$$
\text { . } 994-8 \text { - (1) }
$$

1ا-قواعد الأحكام في مصالح الأنام المؤلف: أبو عحم عز الدين عبد العزيز بن عبد السلام بن أبي القاسم بن الحسن السلمي الدمشقي، الملقب بسلطان العلماء ت • 77 7ه، راجعه وعلق عليه: طه عبد الرؤوف سعد الناشر : مكتبة

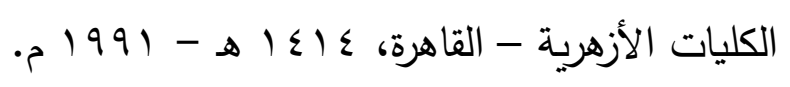

rا-الموافقات، المؤلف: إبراهيم بن موسى بن حمد اللخمي الغرناطي الثهير بالشاطبي ت . . وه، المحقق: أبو عبيدة مشهور بن حسن آل سلمان،

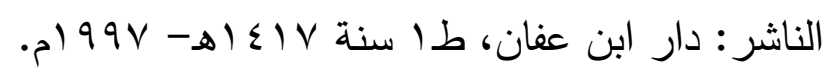

با -شرح التلويح على التوضيح المؤلف: سعد الدين مسعود بن عمر التفتازاني

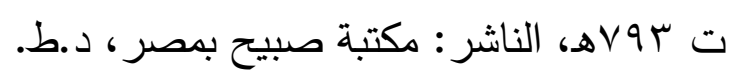

ع ا-البحر المحيط في أصول الفقه، المؤلف: أبو عبد الله بدر الدين عحم بن عبد الله بن بهادر الزركثي ت ع9 \ه، الناشر: دار الكتبي، طا سنة

$$
\text { . } 995-8 \text { - اله }
$$

ه - قواعد ابن الملقن أو 》الأشباه والنظائر في قواعد الفقه المؤلف: سراج

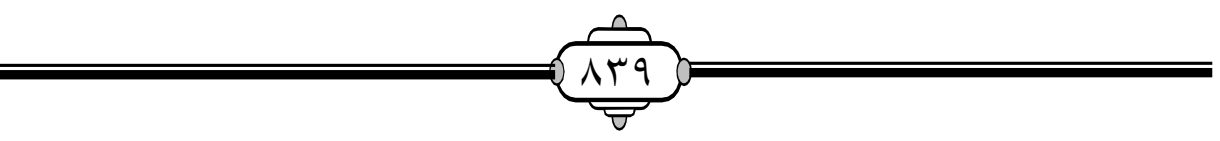


الدين أبو حفص عمر بن علي الأنصاري المعروف بـ ابن الملقن ت ؟ .

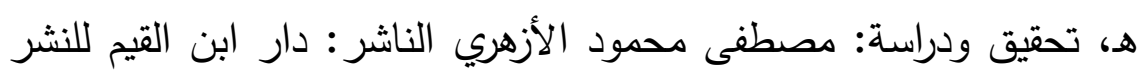
والتوزيع، الرياض - المملكة العربية السعودية، دار ابن عفان للنشر

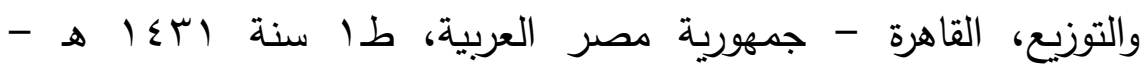
. 1 .

7 ا-الأشباه والنظائر في قواعد وفروع فقه الثافعية المؤلف: جلال الدين عبد

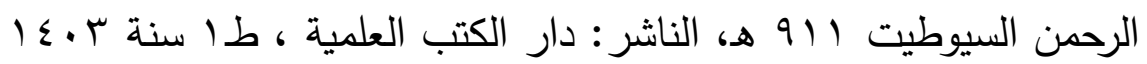

$$
\text { هـ - ه }
$$

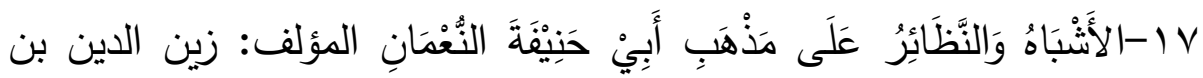
إبراهيم بن تحم، الشهير بابن نجيم ت .9V هـ، وضع حواشيه وخرج أحاديثه: الثيخ زكريا عميرات، الناشر : دار الكتب العلمية، بيروت - لبنان،

$$
\text { طا سنة 19 1999 1 19 م. }
$$

1 - درر الحكام في شرح مجلة الأحكام المؤلف: علي حيدر خواجه أمين أفندي ت سه اهـ، تعريب: فهمي الحسيني الناشر: دار الجيل، طا ما

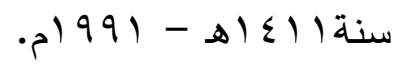

9 ا - مؤسُوعَة القَواعِد الفِقْهِيَّة المؤلف: محمد صدقي بن أحمد بن عحمد آل بورنو أبو الحارث الغزي الناشر: مؤسسة الرسالة، بيروت - لبنان ، طا سنة

$$
\begin{aligned}
& \text {. } r \text { r } \\
& \text { خامسًا: كتب الفقه المذهبي. } \\
& \text { أـ الفقه الحنفي. }
\end{aligned}
$$

• ب-المبسوط المؤلف: حمح بن أحمد بن أبي سهل شمس الأئمة السرخسي (ت س^یه) الناشر: دار المعرفة - بيروت الطبعة: بدون طبعة تاريخ النشر:

$$
\text { . } 999-8 \text { - أه }
$$

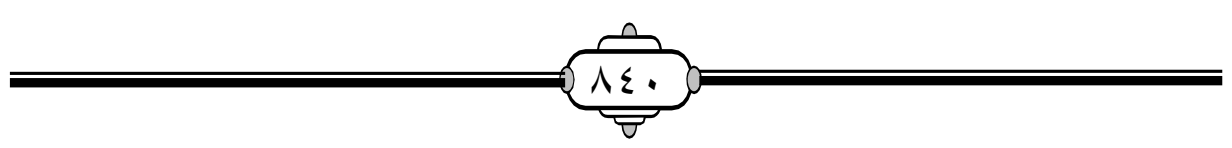




\section{التسويق الشبكي إشكالياته ومعالجاته الفقهية}

اب- بدائع الصنائع في ترتيب الشرائع المؤلف: علاء الدين، أبو بكر بن مسعود بن أحمد الكاساني الحنفي ت OAV، الناشر: دار الكتب العلمية،

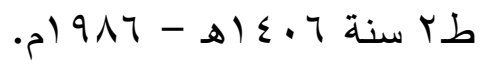

Y Y-رد المحتار على الدر المختار، تأليف: ابن عابدين، محمد أمين بن عمر بن عبد العزيز عابدين الدمشقي الحنفي ت بor اهـ، الناشر: دار الفكر -

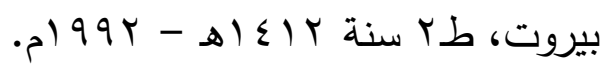

\section{بـ الفقه المالكي.}

سץ-شرح مختصر خليل للخرشي، المؤلف: خحمد بن عبد الله الخرشي المالكي

$$
\text { أبو عبد الله ت } 1 \text { ـ الهـ، الناشر: دار الفكر للطباعة - بيروت. }
$$

ع ب-التاج والإكليل لمختصر خليل، المؤلف: ححمد بن يوسف بن أبي القاسم بن يوسف العبدري الغرناطي، أبو عبد الله المواق المالكي ت \૧هـ، الناشر:

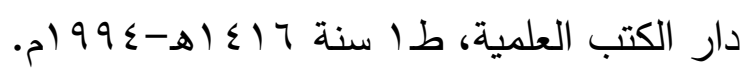

ه ب-الذخيرة، أبو العباس شهاب الدين أحمد بن إدري بن عبد الرحمن المالكي الشهير بالقرافي ت ع آهـ، ط دار الغرب الإسلامي- بيروت، طا سنة . $199 \leq$

جب-الجمع والفرق (أو كتاب الفروق) المؤلف: أبو ححم عبد الله بن يوسف الجويني ت ^ی؟ هـ، تحقيق ودراسة: عبد الرحمن بن سلامة بن عبد الله المزيني، الناشر : دار الجيل للنشر والطباعة والتوزيع - بيروت، طا سنة

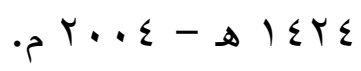

ry الدسوقي المالكي ت • ب إه، الناشر: دار الفكر ، د.ط. 
^ץ-روضة الطالبين وعمدة المفتين المؤلف: أبو زكريا محيي الدين يحيى بن شرف النووي ت تVTV7، تحقيق: زهير الشاويش الناشر: المكتب الإسلامي، بيروت- دمشق - عمان طاس سنة ب إ؛ اهـ - 991 (م. qץ-الحاوي الكبير في فقه مذهب الإمام الشافعي وهو شرح مختصر المزني المؤلف: أبو الحسن علي بن حمح بن ححمد بن حبيب البصري البغدادي، الشهير بالماوردي ت .0؟ه، المحقق: الشيخ علي خحم معوض - الثيخ عادل أحمد عبد الموجود الناشر: دار الكتب العلمية، بيروت - لبنان، طا سنة 1919 1999-199 م.

• r-المجموع شرح المهذب (مع تكملة السبكي والمطيعي)، المؤلف: أبو زكريا محيي الدين يحيى بن شرف النووي ت ד T7ه، الناشر : دار الفكر • د.ن. اس-نهاية المحتاج إلى شرح المنهاج، المؤلف: شمس الدين تحمد بن أبي العباس

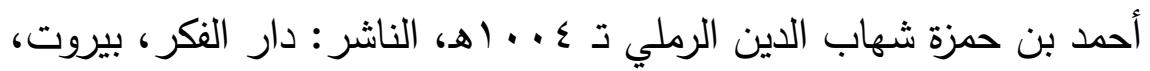

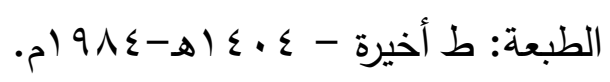
rr-حاشيتا قليوبي وعميرة، المؤلف: أحمد سلامة القليوبي وأحمد البرلسي عميرة، الناشر : دار الفكر - بيروت، د.ط، سنة 0 إـ (هـ-900 (م. د ــ الفقه الحنبلي.

سب-كشاف القناع عن متن الإقناع، المؤلف: منصور بن يونس بن صلاح الدين ابن حسن بن إدريس البهوتى الحنبلى ت 01 ـ إه، الناشر: دار الكتب العلمية.

ع ب-المغني، المؤلف: أبو ححمد موفق الدين عبد الله بن أحمد بن قحمد بن قدامة الجماعيلي المقدسي ثم الدمشقي الحنبلي، الثهير بابن قدامة المقدسي ت

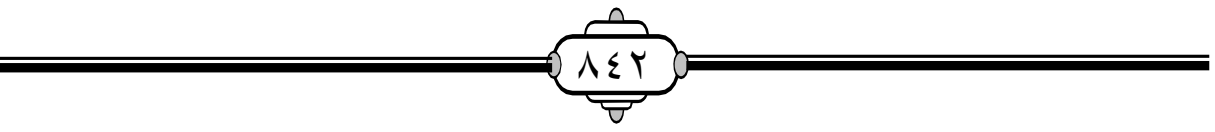


• ب Tه، الناشر : مكتبة القاهرة، د.ط.

هب-شرح منتهى الإرادات - المسمى: 》دقائق أولي النهى لشرح المنتهى"

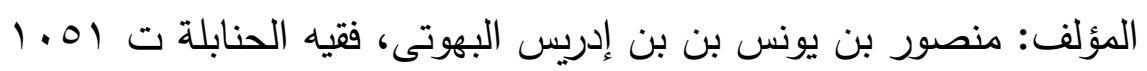

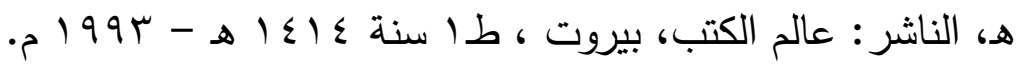
جب-مجموع الفتاوى، المؤلف: تقي الدين أبو العباس أحمد بن عبد الحليم بن

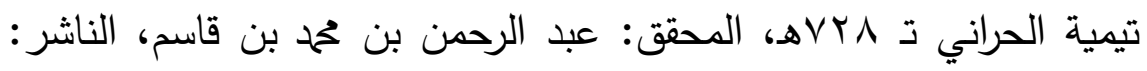
مجمع الملك فهد لطباعة المصحف الثريف، المدينة النبوية، المملكة العربية السعودية، عام النشر : 17 (اء اهـ-990 (م. V V-إعلام الموقعين عن رب العالمين، المؤلف: محمد بن أبي بكر بن أيوب بن

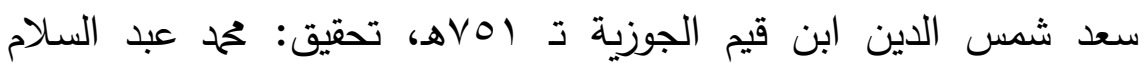
إبراهيم، الناشر: دار الكتب العلمية - ييروت، طا سنة الـأهـ -

سادسًا: كتب الفقه العام والاقتصاد.

^r-التسويق الشبكي، دراسة في ضوء فقه المآلات، د. طه أحمد الزيدي، لإصدارات المجمع الفقهي العراقي، طـ دار الفجر للنشر والتوزيع، ط

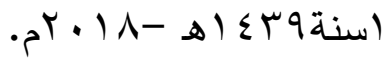

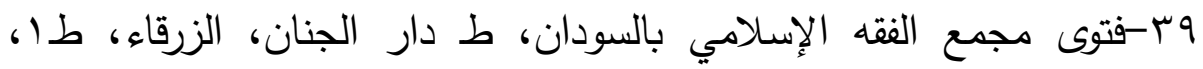

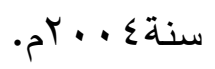

• ع-تعريف عقلاء الناس بحكم معاملة بزناس، علي حسن عبدالحميد الحلبي،

$$
\text { الناشر : دار الجنان - الزرقاء - د.ت. }
$$

إ-مزيل الإلباس عن حكم التعامل مع شركة بزناس biznas ومثيلاتها من شركات التسويق الشبكي، د. مرهف عبدالجبار السقا، سلسة فقه المعاملات،

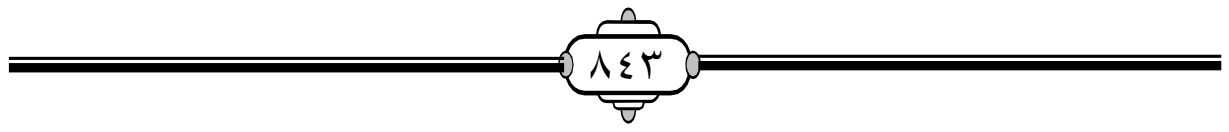


الطبعة الأولى، الناشر : مؤسسة الرسالة، سنة ؟ . . بم.

سابعًا: بحوث ومقالات.

rצ-التسويق الشبكي في ضوء مقاصد البيوع، د. وصفي عاشور، منشور

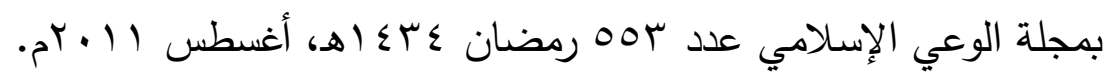

بـ-التسويق الشبكي تحت المجهر، لزاهر سالم بلفقيه [ اشتر لتسوق فقد تكسب]، بحث منشور على موقع صيد الفوائد الإسلامية عبر هذا الرابط: http://www.saaid.net/book/ $r / \varepsilon T \vee \vee p d f$. ؟ء-حكم التسويق الشبكي بعمولة هرمية، دراسة فقهية قانونية مقارنة، أحمد سمير قرني، بحث منشور بمجلة الحق، الصادرة عن لجنة البحوث

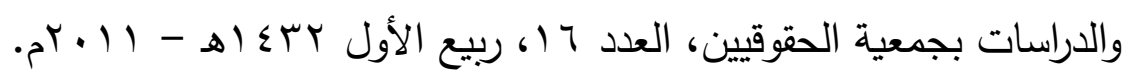
0ـ-بحث التسويق الشبكي، تكييفه وأحكامه الفقهية، بندر بن صقر الذياني، إشراف د. يوسف الشبيلي، المعهد العالي للقضاء، سنة 0بء اهـ ד

T؟ - التسويق الشبكي ( حقيقته وحكمه)، د. محمد الصواط، بحث منشور بمجلة

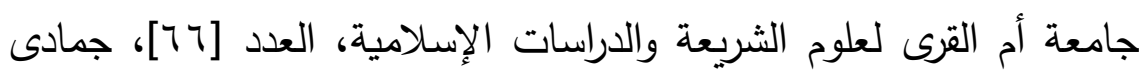

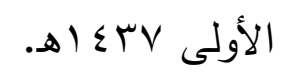

V V -التسويق الشبكي من المنظور الفقهي، لأسامة عمر الأشقر، بحث منشور

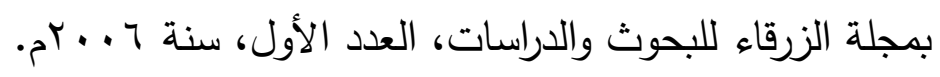
^ـ-التسويق الشبكي [ الهرمي] من وجهة نظر إسلامية، خالد الجهني، بحث منشور شبكة الألوكة الالكتروني. 9؟-الحكم الشرعي في التسويق الشبكي، عبدالرزاق شرع، بوزيد كيحول، بحث منشور بمجلة روافد للبحوث والدراسات ، العدد الثاني، سنة V V • rم. • •-التسويق الشبكي، دراسة شرعية، بحث منشور بمجلة جامعة الناصر ، العدد 位 


$$
\text { الثالث، يناير - يونيو ، سنة ع ا • بام. }
$$

اه-التسويق الشبكي بين الحلال والحرام، نجلاء عبدالمنعم، مركز أبحاث فقه https://kantakji.com/6101 المعاملات الإسلامية، الرابط:

ror-التسويق الشبكي في القواعد الشرعية، ا.د. حسين شحاتة، منشور على موقع دار المشورة للإقتصاد الإسلامي، www.darelmashora.com به-شبهات حول التسويق الشبكي، د. حسين شحاتة، منشور على موقع دار

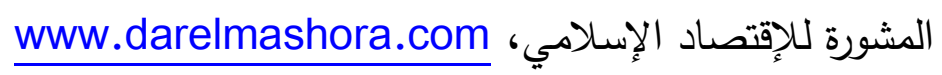
عه-التسويق الشبكي محرم فاجتنبوه، منشور عذبر الرابط: www.darelmashora.com

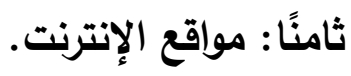
http://www.saaid.net-00 www.nastv.com/islam.htm,www.nastv.com/ml m.htm-or http://:www.islamonline.net/livefatwa/arabic/Browse.asp-ov http://www.zuhayli.com/fatawa_p36.htm\#2-o^ http://www.zuhayli.com/fatawa_p36.htm\#2-oq https://www.almeshkat.net/fatwa-. http://www.islamtodayhttps://www.aliftaa.jo/Question.aspx?Questionld=644\#.YZZsitLP0ps http://www.aliftaa.net/default.aspx.?languagenamehttp://www.dar-aliftaa.org/viewfatwa.aspxid - http:///islamicfatwa.net/fatwa/index.php?module-fatwa.id-37178

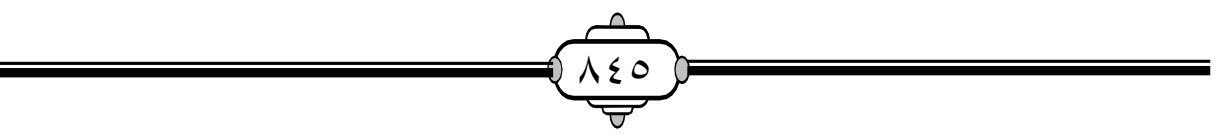


التسويق الثبكي إثكالياته ومعالجاته الفقهية

darelmashora.com- -7

http://www.meshkat.net/assay/biznasfatwa2.htm- - v

http://www.mlm-thetruth.com/ShockingMLMstats.htm-ฯ^ 